\title{
Some effects of associated growth on grass and clover under field conditions
}

\author{
JANNY A. BAKHUIS and H. J. KLETER \\ Department of Field Crops and Grassland Husbandry, Agricultural University, \\ Wageningen, Netherlands
}

\section{Summary}

A two-year field experiment with pure stands of white clover, perennial ryegrass and cocksfoot. with alternate rows of clover and the grass species, and with separated and unseparated root systems on a nitrogen-deficient soil is discussed.

It is shown that nitrogen transfer from clover to grass takes place through loss of leaves and leaching of nitrogen from the above-ground parts. The mutual effects of the species are analysed.

\section{Introduction}

Grass grown in association with clover seems to profit in some way from the latter's presence. This is confirmed by numerous experiments, but in others every beneficial effect appears to be absent ${ }^{1}$. The phenomenon may not occur under all circumstances or the beneficial effect may be obscured by opposing factors. Most investigators assume that the stimulating effect on the associated gramineae is caused by excretion or release of nitrogen compounds from the legume roots and nodules into the soil. The increase in nitrogen content of the grass has often been looked upon as a proof of this transfer of nitrogen. However, it is possible that the legume does not compete with nonlegumes for soil nitrogen so that this increase in nitrogen content may be due to the lower number of non-legume plants in a mixture compared with a pure stand. Thus a clear proof of transfer is only obtained when the nitrogen yield of grass grown in association with clover is higher than that of a pure grass stand. On the other hand, from the absence of such an increase of nitrogen yield may not be concluded that clover does not excrete or release nitrogen, as this legume may take up some nitrogen from the soil or the grass may utilize the soil nitrogen less effectively. Only few authors mention an increase of nitrogen content and yield of grass grown in association with clover.

Any direct nitrogen effect may be due to nitrogen excretion during the growth of the leguminous plants or nitrogen release as a result of the decomposition of decaying roots and nodules. Some authors agree with the first explanation, some advocate the second, and others support both. Whatever the mechanism, the extent to which grass profits by clover nitrogen depends on the circumstances. Growing conditions resulting in a small $\mathrm{C} / \mathrm{N}$ quotient should favour nitrogen excretion provided photosynthesis is great enough to ensure sufficient nitrogen fixation.

1 Due to prolonged illness of the first author no proper references to literature could be made, but the literature consulted is listed at the end of the paper.

Received for publication 25th November, 1964. 

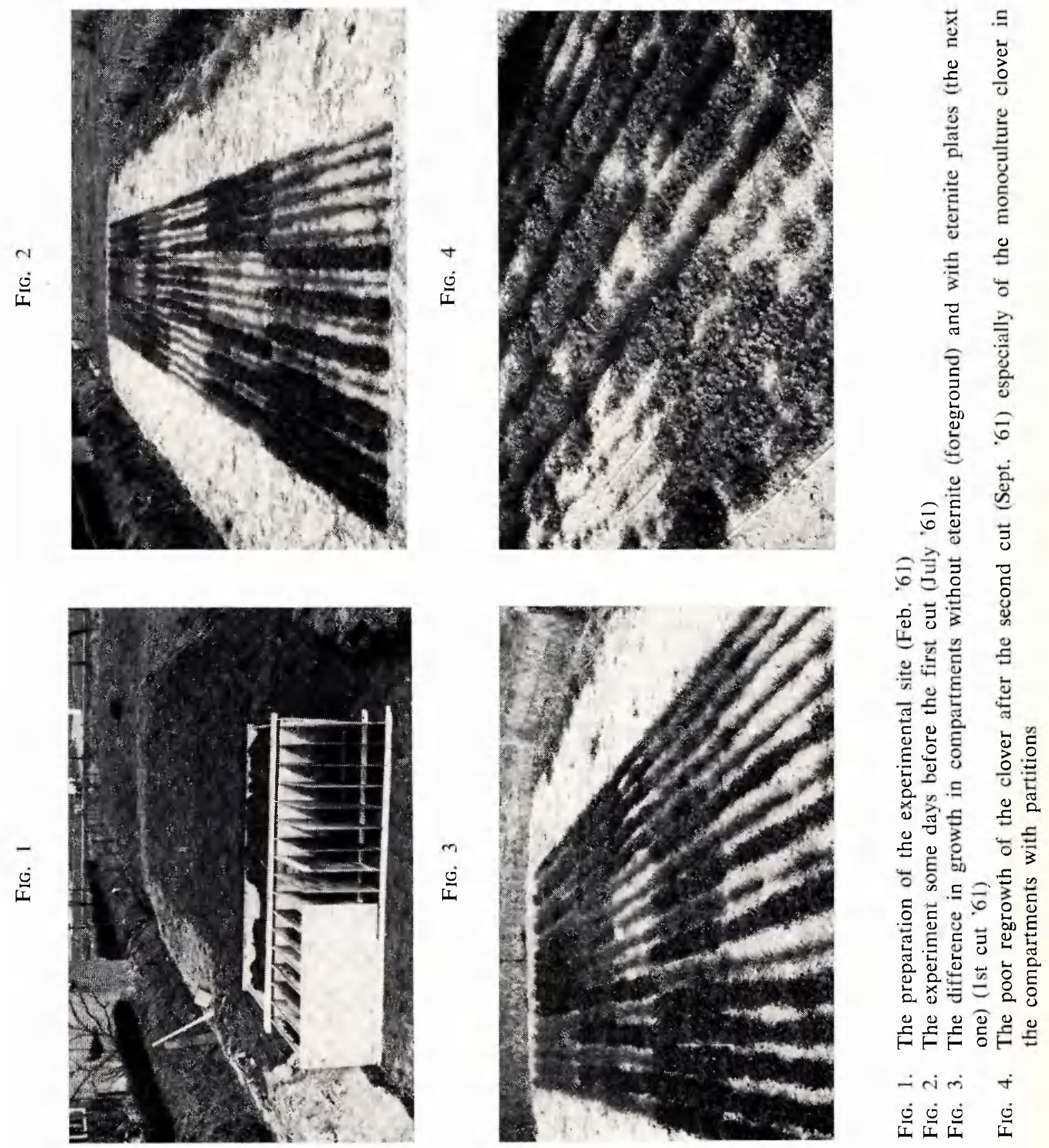
FIG. 5a

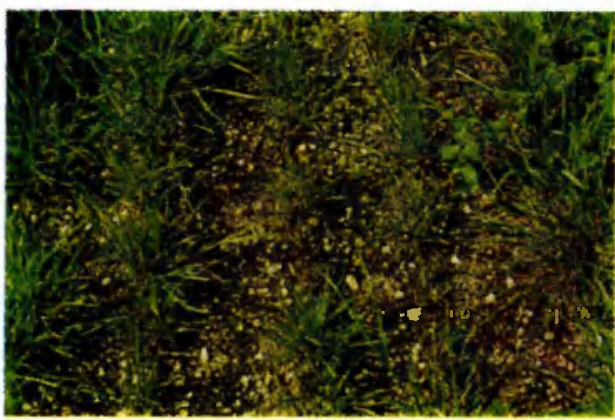

FIG. $6 a$

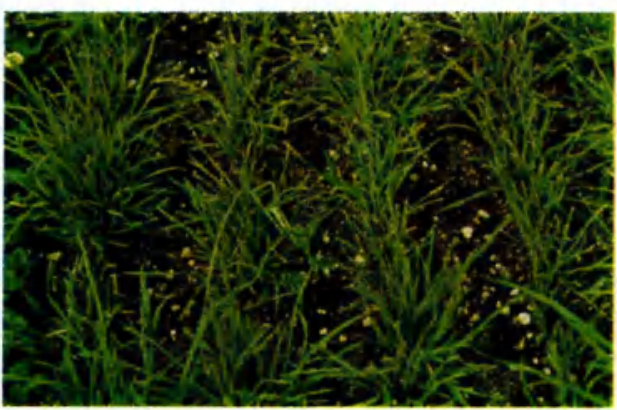

FIG. $5 b$

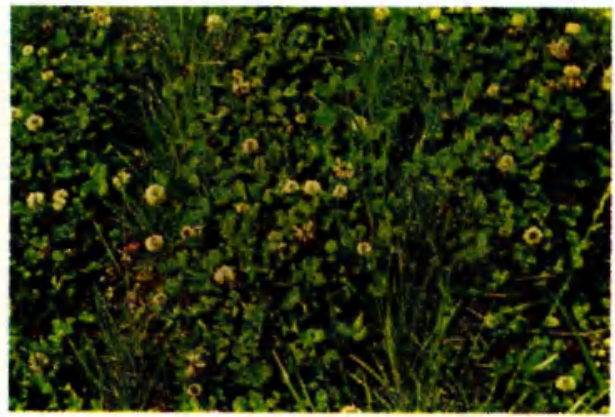

FIG. $6 b$

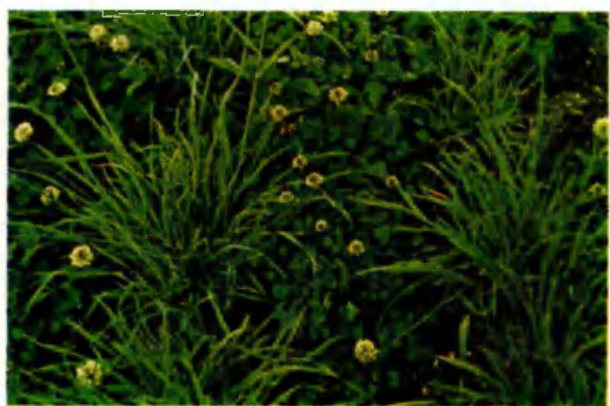

FIG. 5. Difference in growth of perennial ryegrass before the second cut in 1962 (13 July '62);

a. in between perennial ryegrass.

b. in between white clover.

Fig. 6. Difference in growth of cocksfoot before the second cut in 1962 (13 July '62);

a. in between cocksfoot.

b. in between white clover. 
As appears from literature, conditions in the Netherlands are very favourable for nitrogen excretion (long days, moderate temperatures and low light intensities) and also for periodical decay of roots and nodules (frequent defoliation, repeated nitrogen fertilization, alternately unclouded and overcast, and a varied water supply).

Under field conditions it is difficult to determine whether nitrogen transfer from clover to grass has taken place. Most investigations on nitrogen transfer from legumes to graminaceous plants were carried out in pots under greenhouse conditions and with seedlings or young plants. RusseLl reported in 1953 that field experiments on these problems were very scarce. BLACK mentioned in 1957 that "the importance of the transfer of nitrogen from a legume to an associated non-legume crop under field conditions has been shrouded with uncertainty". Evidently, field experiments are needed. There is another reason to investigate this subject: - in many publications much attention has been paid to the beneficial effect of clover on grass through transfer of nitrogen in the soil, while other possible causes have been neglected.

This paper describes a field experiment which gives some results on the above-ground and underground effects of grass and white clover on themselves and on their associates.

\section{Material and methods}

An experiment with grass and clover rows was set up by the CHAMBLEE method (1958) in which a part of the rows was separated under the ground by eternite plates to a depth of $60 \mathrm{~cm}$. For this purpose the soil was excavated and the eternite plates were held in a vertical position by wooden frames (FIG. 1). After breaking up the clay bottom and refilling as uniformly as possible with a sandy soil, the wooden upper frame was removed. The construction was completed in early March to give the soil chance to settle. Fig. 7 represents a replicate consisting of one compartment with and one without partitions. Each compartment contains 16 rows of grass and clover in various combinations, and each row has a length of $1.25 \mathrm{~m}$ and a distance of $15 \mathrm{~cm}$ from the adjacent rows. Six replicates were placed next to each other in a north-south direction (FIG. 8). The three northern replicates were sown with Lolium perenne and Trifolium repens, the three southern ones with Dactylis glomerata and Trifolium repens. The units of pure grass, pure clover and alternate rows of grass and clover in the east-west direction were randomized within the replicates (FIG. 8). In each of the twelve compartments $565 \mathrm{mg}$ of perennial ryegrass (hay type, late flowering), $375 \mathrm{mg}$ of cocksfoot and $375 \mathrm{mg}$ of white clover per row were sown on 12th May. The ratios of seed quantities of ryegrass, cocksfoot and white clover were obtained from KLAPP (1954).

Soil analyses to a depth of $25 \mathrm{~cm}$ in 1961 and 1962 are given in TABLE 1 . After the second cuts in August 1961 and July 1962 the soil was uniformly fertilized (kg/ha) as follows: -

\begin{tabular}{|c|c|c|}
\hline & 1961 & 1962 \\
\hline $\mathrm{K}(\mathrm{KCl})$ & 133 & 104 \\
\hline P (super phosphate) & 一 & 33 \\
\hline Mg (kieserite) $\ldots \ldots$ & 39 & 45 \\
\hline
\end{tabular}

After sowing and in June 1961 the field was sprinkled. The soil was weeded and its surface slightly broken up when necessary.

The herbage of each row was separately clipped and oven-dried at $70^{\circ} \mathrm{C}$ (TABLE 2). The clover was harvested in 1962 and 1963, but not weighed, because formation of runners made it difficult to harvest each row separately. Taking FIG. 7 as an example, 
FIG. 7. A replicate consisting of one compartment with and one without partitions

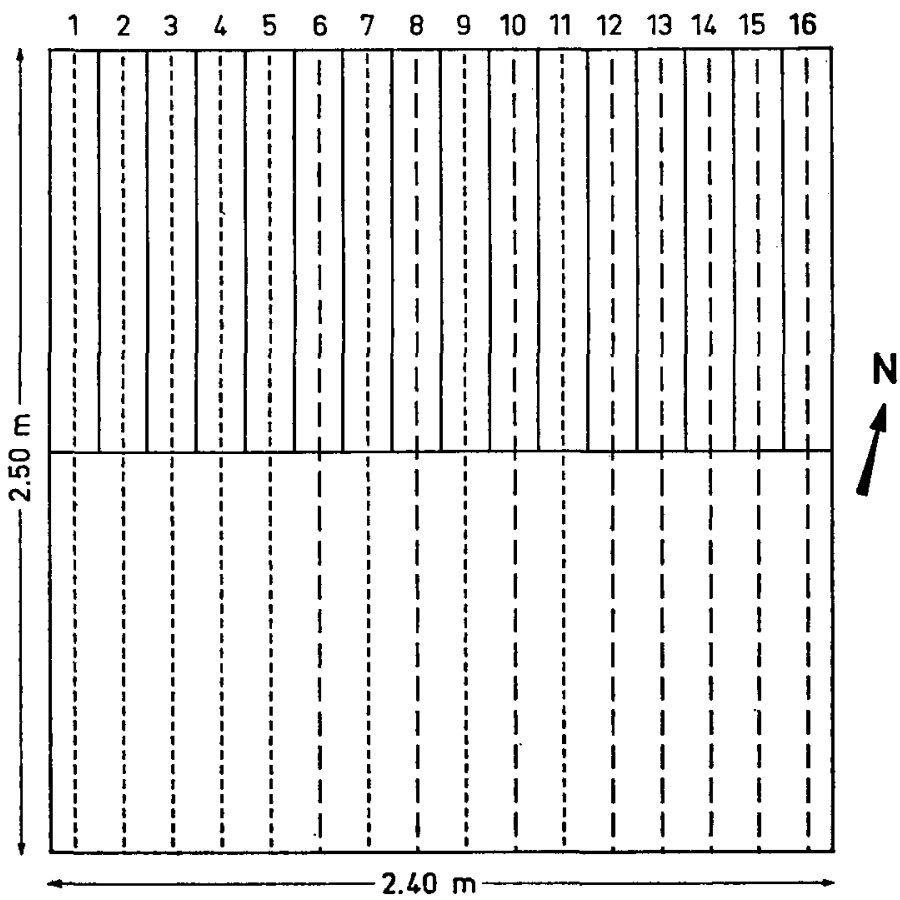

_- white clover

FIG. 8. Lay-out of the experimental field

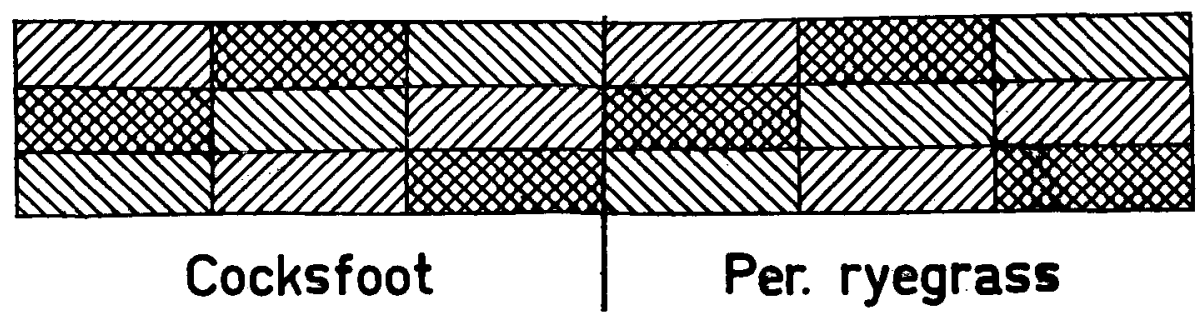

\section{MIV grass}
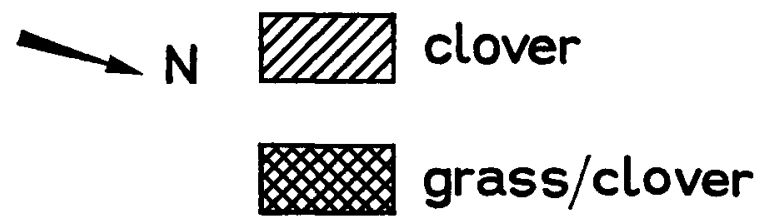
TABLE 1. Analyses of the soil

\begin{tabular}{|c|c|c|}
\hline & 1961 & 1962 \\
\hline $\mathbf{p H}-\mathbf{K C l} \ldots \ldots$ & 6.5 & 6.1 \\
\hline Humus $(G) \% \ldots \ldots \ldots \ldots$ & 2.0 & 2.0 \\
\hline $\mathrm{CaCO}_{3} \% \ldots \ldots \ldots \ldots$ & 0.1 & 0.1 \\
\hline Clay $\% \quad \ldots \ldots \ldots \ldots \ldots \ldots$ & 7 & - \\
\hline Sand $\%$ coarse $\ldots \ldots \ldots \ldots \ldots$ & 64 & - \\
\hline total $\ldots \ldots \ldots \ldots \ldots \ldots$ & 91 & - \\
\hline $\mathbf{P}-\mathbf{A L} \quad \ldots \ldots \ldots \ldots \ldots \ldots \ldots$ & 77 & 75 \\
\hline $\mathrm{K} 1 / 1000 \%$ & 9 & 11 \\
\hline $\operatorname{MgO} 1 / 10000 \%$ & 27 & 30 \\
\hline $\mathbf{N}$ (total) $\% \quad \ldots \ldots \ldots \ldots \ldots$ & - & 0.05 \\
\hline $\mathbf{N}$ (water) $\% \ldots \ldots \ldots \ldots \ldots$ & 1 & 0 \\
\hline
\end{tabular}

TABLE 2. Dates of harvesting

\begin{tabular}{|c|c|c|c|c|c|c|c|}
\hline \multirow[b]{2}{*}{$\begin{array}{l}\text { 1st cu } \\
\text { 2nd ", } \\
\text { 3rd " } \\
\text { 4th ", }\end{array}$} & \multirow[b]{2}{*}{$\begin{array}{l}\ldots \ldots \\
\ldots \ldots \\
\ldots \ldots \\
\ldots \ldots\end{array}$} & \multicolumn{2}{|l|}{1961} & \multicolumn{2}{|l|}{1962} & \multicolumn{2}{|c|}{1963} \\
\hline & & $\begin{array}{l}\text { July } \\
\text { August } \\
\text { September } \\
\text { October }\end{array}$ & $\begin{array}{l}13 \text { th } \\
8 \text { th } \\
12 \text { th } \\
26 \text { th }\end{array}$ & $\begin{array}{l}\text { June } \\
\text { July } \\
\text { September }\end{array}$ & $\begin{array}{l}\text { 6th } \\
19 \text { th } \\
19 \text { th }\end{array}$ & May & 24th \\
\hline
\end{tabular}

the grass rows $2,3,4$ and $7,9,11$, and the clover rows $6,8,10$ and $13,14,15$ represent plots with grass only, grass in association with clover, clover in association with grass and clover only respectively. No two rows are identical when we take into account the species of the two rows on either side. However, a careful examination of the yields over the two years showed that there was no relation between the yield and the location of the rows in the experiment. Grass row 5 and clover row 12 in FIG. 7 are only adjacent to one row of their own species. Figures relating to these rows have been disregarded because of the unreliability of a single observation.

In the TABLES 3 and 4 the average yield of crude protein and dry matter is presented as a mean of 9 rows. For grass in association with clover and clover with grass only 8 rows were available.

In the analysis of variance the unknown value was calculated by: -

$$
\begin{aligned}
& x=\frac{3 R+2 T r-T}{14} \quad R=\begin{array}{l}
\text { sum of the } 5 \text { experimental values in the con- } \\
\text { cerning replicate. }
\end{array} \\
& \operatorname{Tr}=\text { sum of the } 8 \text { experimental values in the con- } \\
& \text { cerning treatment. } \\
& T=\text { total sum of the } 17 \text { experimental values. }
\end{aligned}
$$

In addition, the results of this experiment were treated according to the competition theory of DE WIT (1960). In this theory the results of competition between two plant species are treated quantitatively and a mathematical approach is applied to the development of the competitive struggle in supersession series. It gives us a few formulae for the relation between seed frequency and seed yield of plant species in a mixed culture. These are for grass and clover: - 


$$
\begin{aligned}
& \mathrm{O}_{\mathrm{g}}=\frac{\mathrm{K}_{\mathrm{gc}} z_{\mathrm{g}}}{\mathrm{K}_{\mathrm{gc}} z_{\mathrm{g}}+\mathrm{z}_{\mathrm{c}}} \mathrm{M}_{\mathrm{g}} \text { and } \\
& \mathrm{O}_{\mathrm{c}}=\frac{\mathrm{K}_{\mathrm{cg}} z_{\mathrm{c}}}{\mathrm{K}_{\mathrm{cg}} z_{\mathrm{c}}+\mathrm{z}_{\mathrm{g}}} \mathrm{M}_{\mathrm{c}}
\end{aligned}
$$

in which $\mathrm{O}_{g}$ and $\mathrm{O}_{c}$ represent the yield of grass and clover, $z_{g}$ and $z_{c}$ the relative seed frequencies of the components in the seed mixture, $\mathbf{M}_{g}$ and $\mathbf{M}_{c}$ the yield of pure stands of similar seed density; $K_{\mathrm{gc}}$ and $\mathrm{K}_{\mathrm{cg}}$, being constants, are measures of the competitive power of each species in the mixture. $\mathbf{K}_{\mathrm{gc}}$ is called the relative crowding coefficient of grass compared with clover. The space occupied by a grass plant surrounded by clover plants is $\mathrm{K}_{\mathrm{gc}} \times$ the space of a clover plant between grass plants. In this experiment the seed frequencies can be given by the relative number of rows and the production of each component by dry-matter or crude-protein yields.

From DE WIT's theory different MODELS of competition can be derived. The MODELS applicable to the results of our experiment are treated on the next pages. The diagrams show the relation between the relative seed frequency $\left(z_{g}\right.$ of grass and $z_{c}$ of clover along the $\mathrm{x}$-axis) and the yield of the components $\left(\mathrm{O}_{\mathrm{g}}\right.$ and $\mathrm{O}_{c}$ along the y-axis). In MODEL I and II the plant species having the same growing period are crowding for the same "space". The term "space" may also comprehend "growth factors" like light, water and mineral supply etc., homogeneously distributed over the field.

The yield of one component in MODEL $I$ is proportional to the quantity of seeds sown in the mixed stand.

MOdeL I: $\quad \mathbf{K}_{\mathrm{gc}} \times \mathbf{K}_{\mathrm{cg}}=\mathbf{1}$

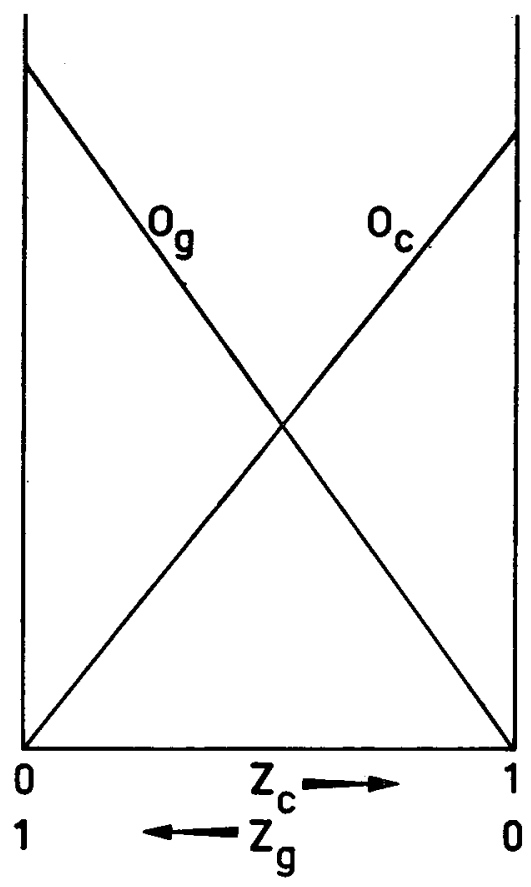

Model II: $\quad \mathrm{K}_{\mathrm{gc}} \times \mathbf{K}_{\mathrm{cg}}=\mathbf{1}$

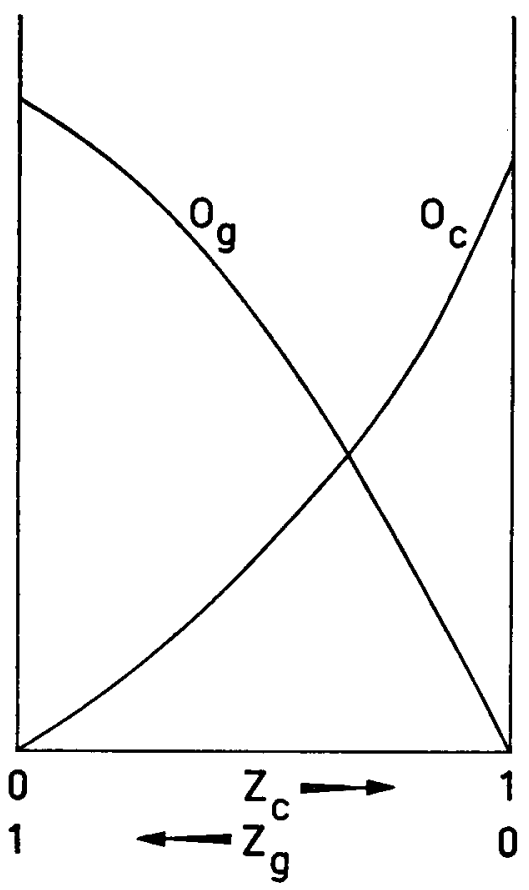

Neth. J. agric. Sci., Vol. 13 (1965) No. 3 (August) 
In MODEL II the yield of one component is not proportional to the quantity of seeds sown, but the sum of the yields in a mixed culture expressed as fractions of the yields in monoculture is 1 .

In MODEL III the sum of the yields in a mixed culture expressed as fractions of the yields in monoculture is larger than 1. The species are crowding for space, which is not completely the same.

a. the explored spaces are partly separated by time (different growth periods);

b. the explored spaces are partly separated by place (different rooting depth, nitrogen fixation etc.). This model should be distinguished from MODEL $V$.

In MODEL IV the sum of the yields in a mixed culture expressed as fractions of the yields in a monoculture is smaller than 1. This may occur when a species is poisonous to the other.

MODEL III: $\quad \mathrm{K}_{\mathrm{gc}} \times \mathrm{K}_{\mathrm{cg}}>1$

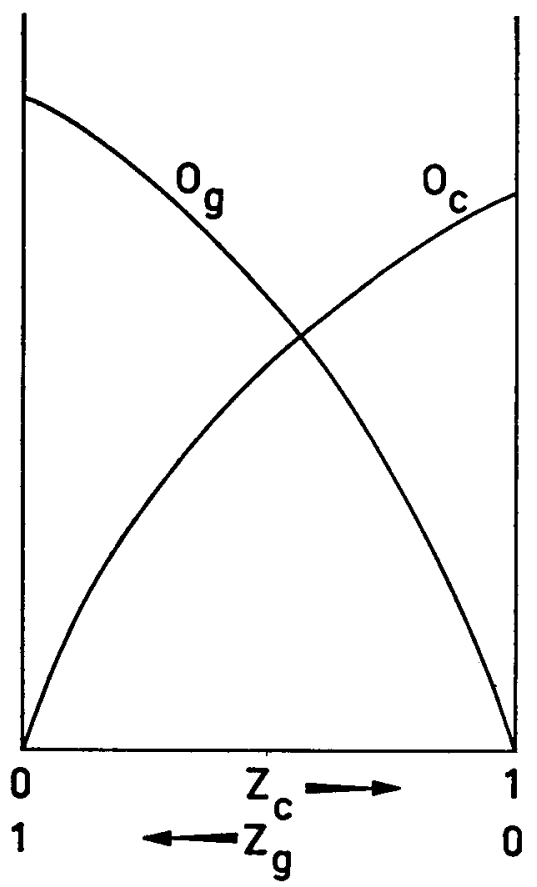

MODeL IV: $\mathrm{K}_{\mathrm{gc}} \times \mathrm{K}_{\mathrm{gc}}<1$

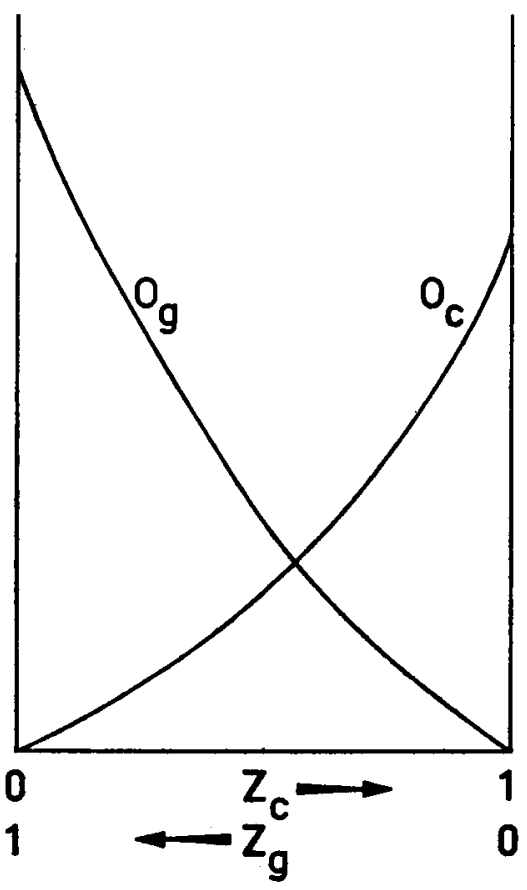

DE WIT did not properly distinguish the case in which a species profits from the presence of another of MODEL III. Then it is possible that in the mixed culture one species yields more per unit of soil surface than in the monoculture. This may occur for instance when grass associated with clover grows and competes better because of the uptake of nitrogen produced by the clover. Now DE WIT's treated this case as follows. In MODEL $\mathrm{V}$ the equation

$$
\mathrm{O}_{\mathrm{c}}=\frac{\left(\mathrm{K}_{\mathrm{cg}}\right)_{\mathrm{z}} \times \mathrm{z}_{\mathrm{c}}}{\left(\mathrm{K}_{\mathrm{cg}}\right)_{\mathrm{z}} \times \mathrm{z}_{\mathrm{c}} \times \mathrm{z}_{\mathrm{g}}} \mathrm{M}_{\mathrm{c}}
$$

is true for any seed frequency. 


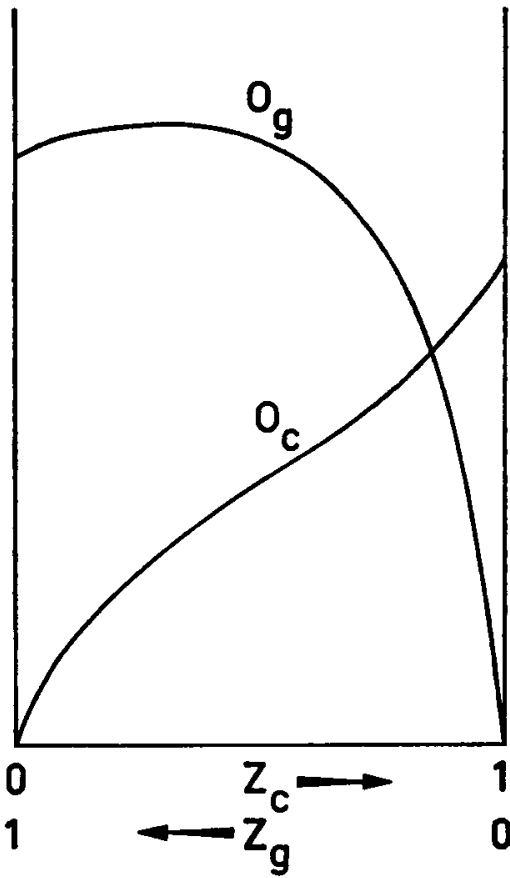

MODEL V

See text

But here $\left(\mathrm{K}_{\mathrm{cg}}\right)_{\mathrm{z}}$ is a decreasing function of the seed frequency of clover, because with decreasing clover content less clover nitrogen is transferred to the grass and the grass becomes less competitive. This function can be calculated from the yield curve of clover by equation (2). For instance, in MODEL $V$ the yield of clover with $z_{c}$ equal to $1.00,0.50$ and 0.20 is $20,10.6$ and 6.0 respectively, so that $\left(K_{c g}\right)_{0.5}$ and $\left(K_{c g}\right)_{0.2}$ are equal to 1.13 and 1.71. The solid line in FIG. 9 gives the relation between $\mathbf{K}_{\mathrm{cg}}$ and $z_{c}$ calculated from the clover yields in MODEL V.

Now in addition, it is either possible that clover and grass crowd for the same space (as in MODEL II) or partly for different spaces. In the first case $\left(K_{\mathrm{gc}}\right)_{z}=1 /\left(\mathrm{K}_{\mathrm{cg}}\right)_{z}$ and the second case $\left(\mathrm{K}_{\mathrm{gc}}\right)_{\mathrm{z}}=\mathrm{c} /\left(\mathrm{K}_{\mathrm{cg}}\right)_{\mathrm{z}}$ in which $\mathrm{c}$ is greater than unity and is constant in the first instance. The dashed line in FIG. 9 presents $\left(\mathrm{K}_{\mathrm{gc}}\right)_{\mathbf{z}}$ calculated on the assumption that $c$ is equal to 3 .

The yield of grass in the mixed stands can be represented by:

$$
\mathrm{O}_{\mathrm{g}}=\frac{\left(\mathrm{K}_{\mathrm{gc}}\right)_{\mathrm{z}} \times \mathrm{z}_{\mathrm{g}}}{\left(\mathrm{K}_{\mathrm{gc}}\right)_{\mathrm{z}} \times \mathrm{z}_{\mathrm{g}}+\mathrm{z}_{\mathrm{c}}}\left(\mathrm{M}_{\mathrm{g}}\right)_{\mathrm{z}}
$$

in which $\left(M_{g}\right)_{z}$ is again a function of $z$. It represents the yield of a monoculture of grass at a nutrient level similar to that created by clover. The relation between $\left(M_{g}\right)_{z}$ and $z_{c}$ calculated from the yield curve of grass in model $V$ and the $K_{g c}-$ curve in FIG. 9 is shown as a dotted line in FIG. 10.

\section{Results}

The grass and clover established themselves very well (FIG. 2), although the stand of 

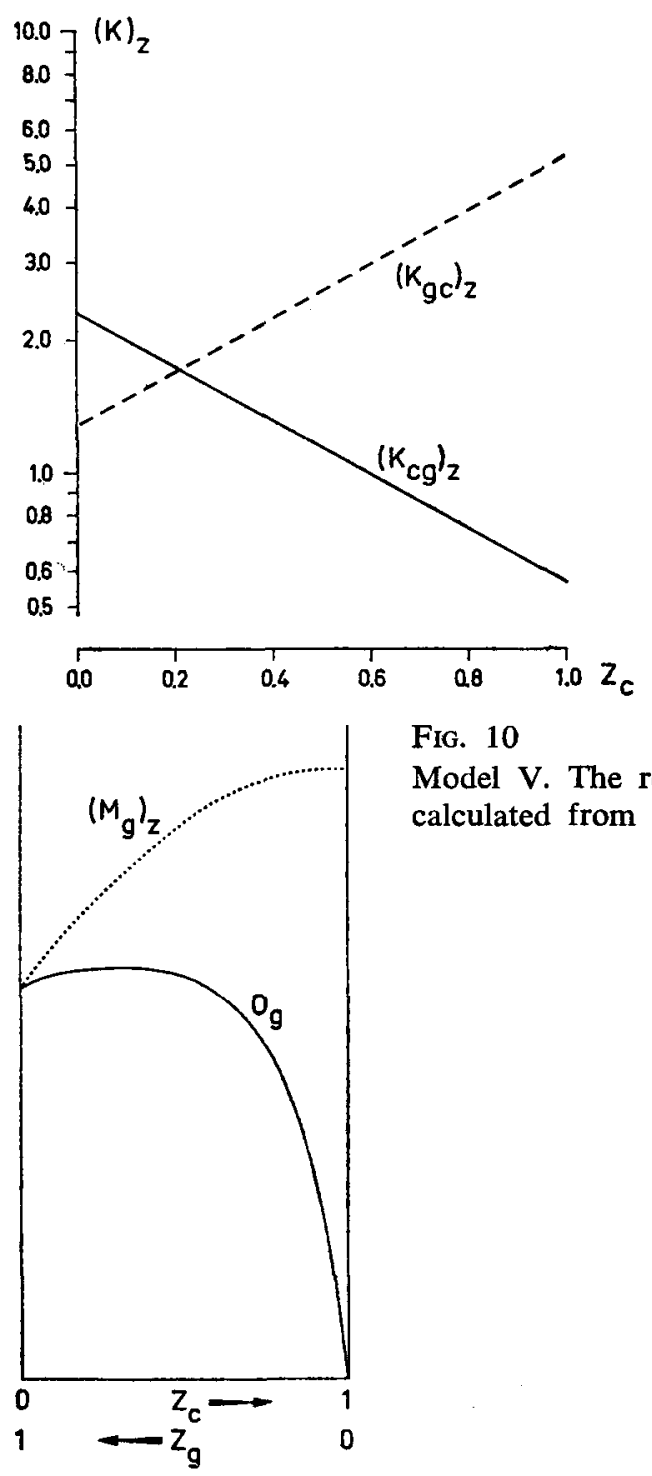

FIG. 10

Model V. The relation between $\mathbf{M}_{\mathrm{g}}$ and $\mathbf{Z}_{c}$ (dotted line) calculated from the yield curve of grass (solid line)

cocksfoot was rather thin at the beginning. The late frost in the latter part of the winter of 1961-1962 did not affect the grass and clover unfavourably.

TABLES 3 and 4 give the average yields of crude protein and dry matter per row of grass only, grass in association with clover, clover only and clover in association with grass, and the coefficients of variance of the individual yield values with and without partitions. The differences between yields of rows in pure and mixed stands within each compartment (the sign indicates whether the difference is in favour of the mixed stand) are also given in these tables.

We have tried to eliminate the difference in yield with and without partitions by 
JANNY A. BAKHUIS AND H. J. KLETER

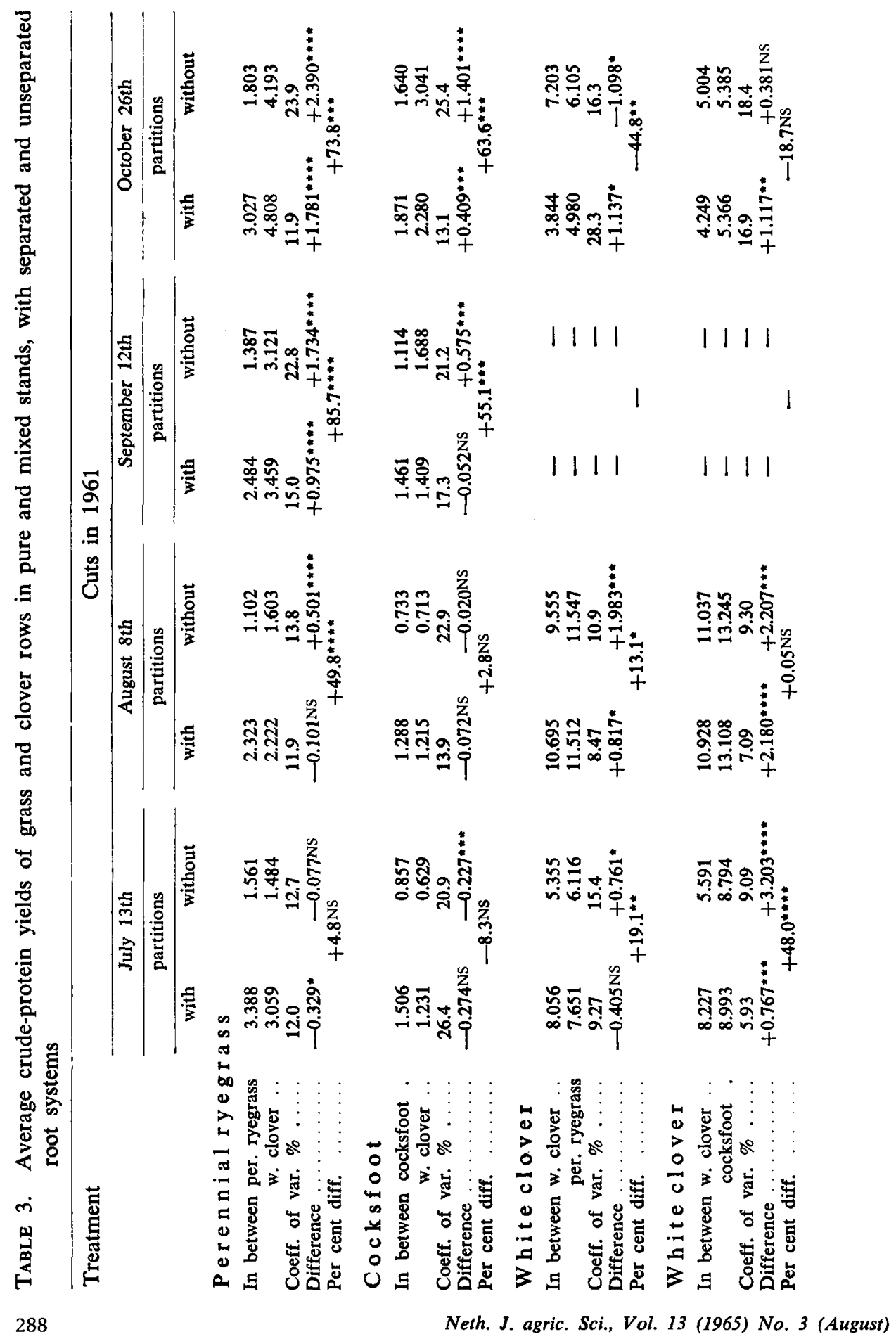



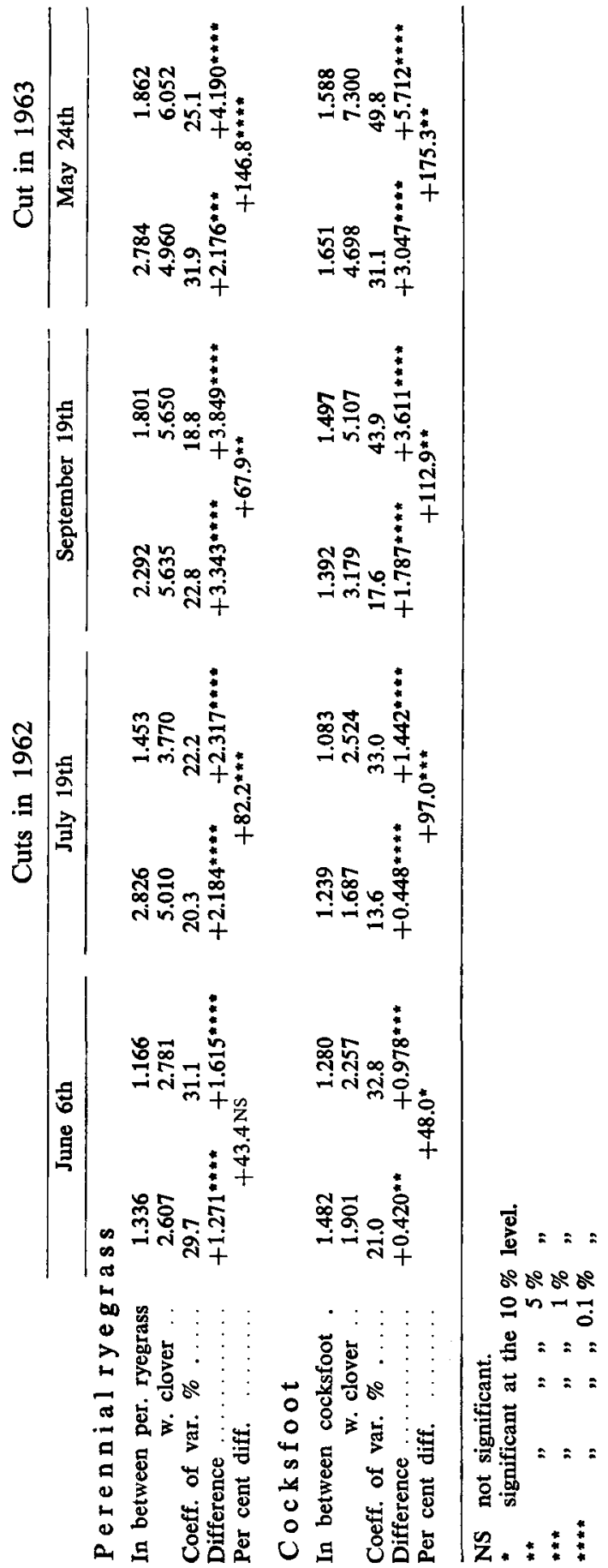

Neth. J. agric. Sci., Vol. 13 (1965) No. 3 (August) 


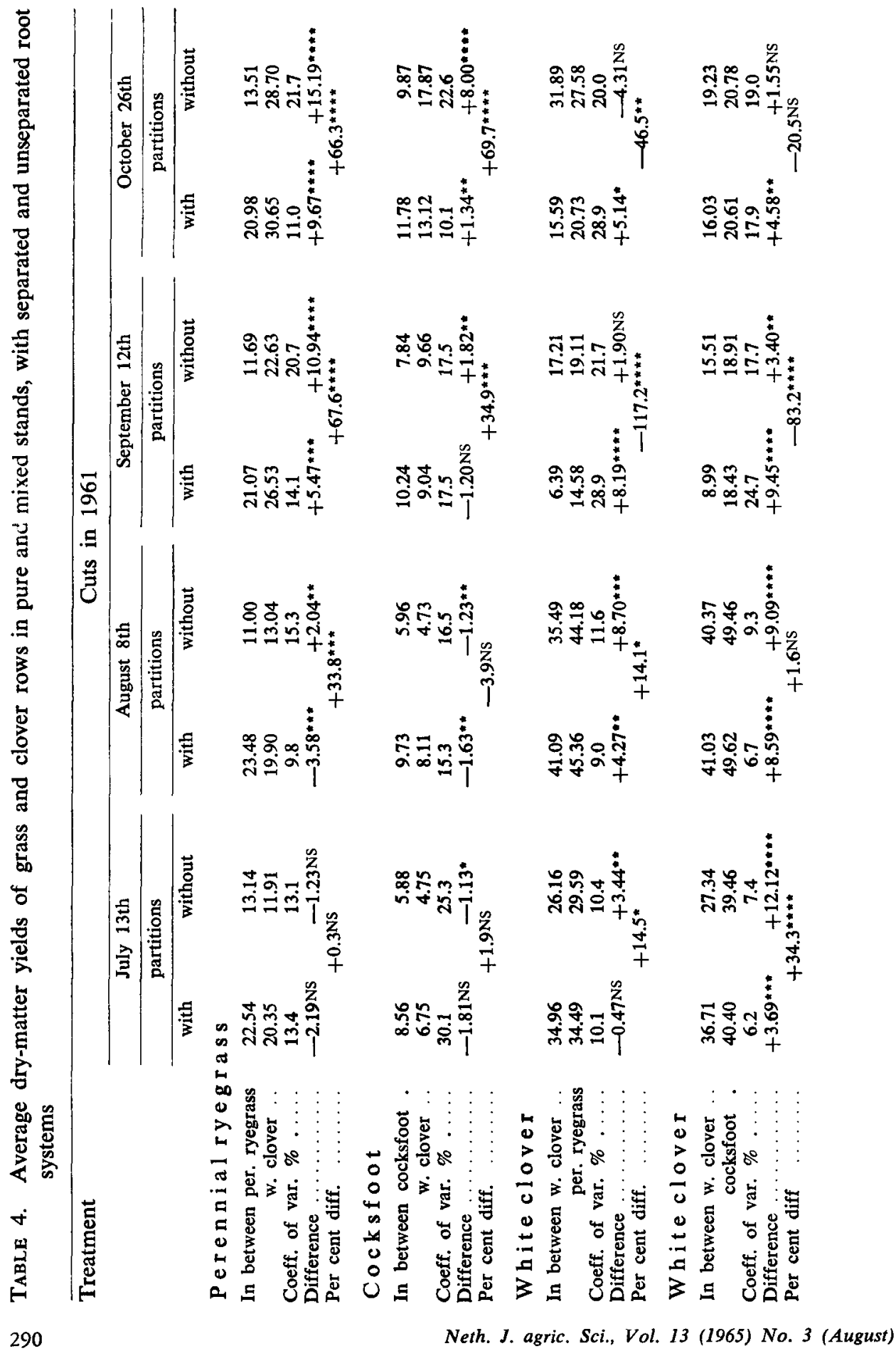


SOME EFFECTS OF ASSOCIATED GROWTH ON GRASS AND CLOVER UNDER FIELD CONDITIONS

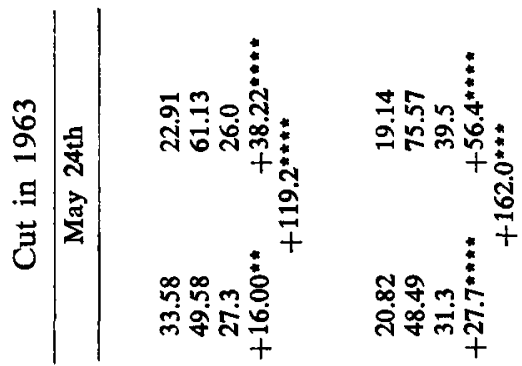

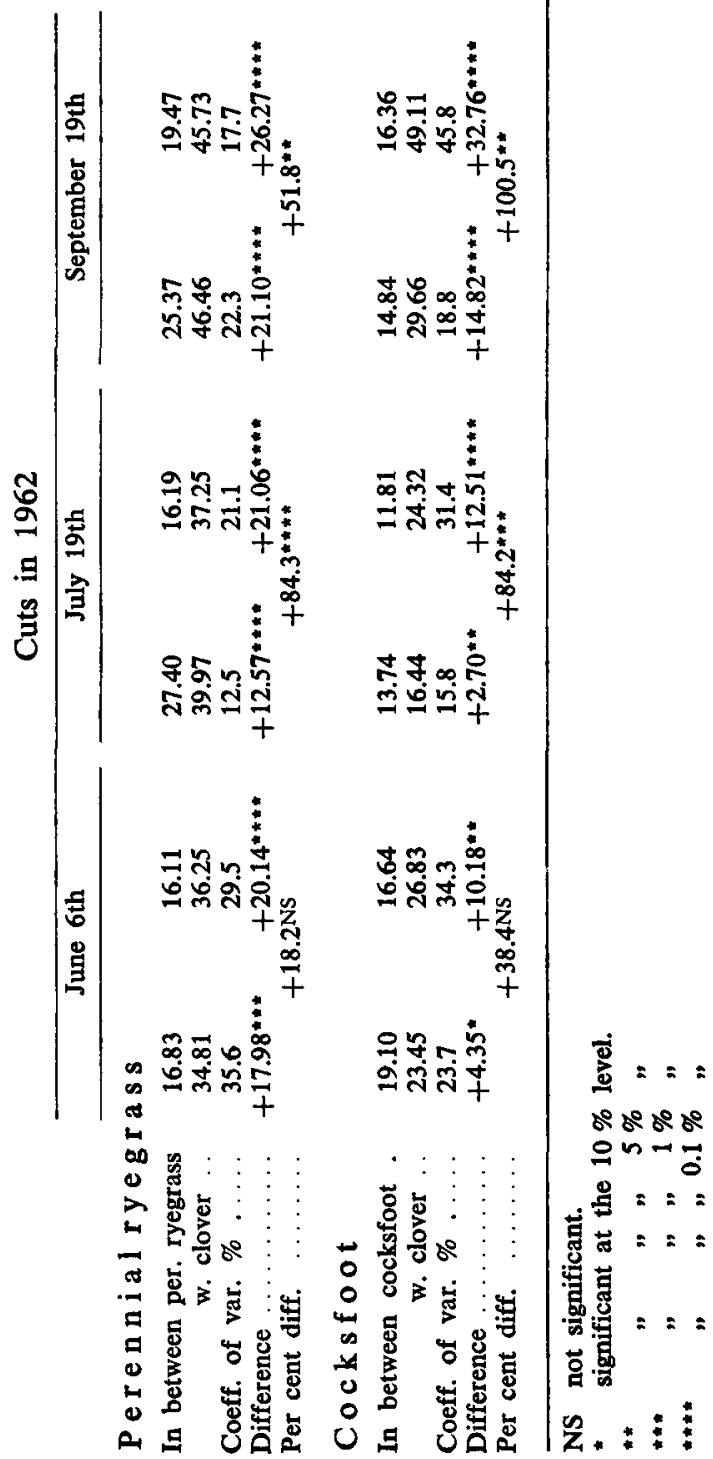

Neth. J. agric. Sci., Vol. 13 (1965) No. 3 (August) 
expressing the yields per row in the mixed cultures as a percentage of the yields in the pure stands. These percentages were subtracted and the differences are given in TABLES 3 and 4 as "per cent differences".

The question arises why the yield values with and without partitions were not compared directly. From the first cut in 1961 onwards there was a great discrepancy in yield of grass and clover between compartments with and without partitions, which cannot be explained by the separation of the root systems only (FIG. 3). During the experiment this discrepancy gradually decreased in clover more rapidly than in grass. It is unlikely that the eternite partitions left any nutritive element in the soil because before starting the experiment the plates were left in the open for two years to give them a chance to leach. Probably these plates kept the soil in a favourable structure, although this was not revealed by physical measurements during the first year. At the end of the experiment in 1963 the roots were dug up. It was observed that relatively more roots were growing close to the plates. Since we also found more active nodules at a greater depth on the clover roots growing close to the plates, we conclude that this "plate factor" was due to a better aeration of the soil near the partitions. The effect of this superior aeration may depend on the kind of soil in the compartments; a similar experiment which was started with another soil in the next year (1962) did not show this phenomenon. In CHambleE's (1958) experiment this complication did not occur either.

FIG. 11 and 12 represent the per cent differences more distinctly. Because we may assume that, firstly, on this very sandy and nitrogen-deficient soil (see TABLE 1) nitrogen limits growth and, secondly, that the relation between nitrogen supply and nitrogen uptake by the grass can be represented by a straight line, these per cent differences in nitrogen (or protein) yield are an estimation of the underground nitrogen

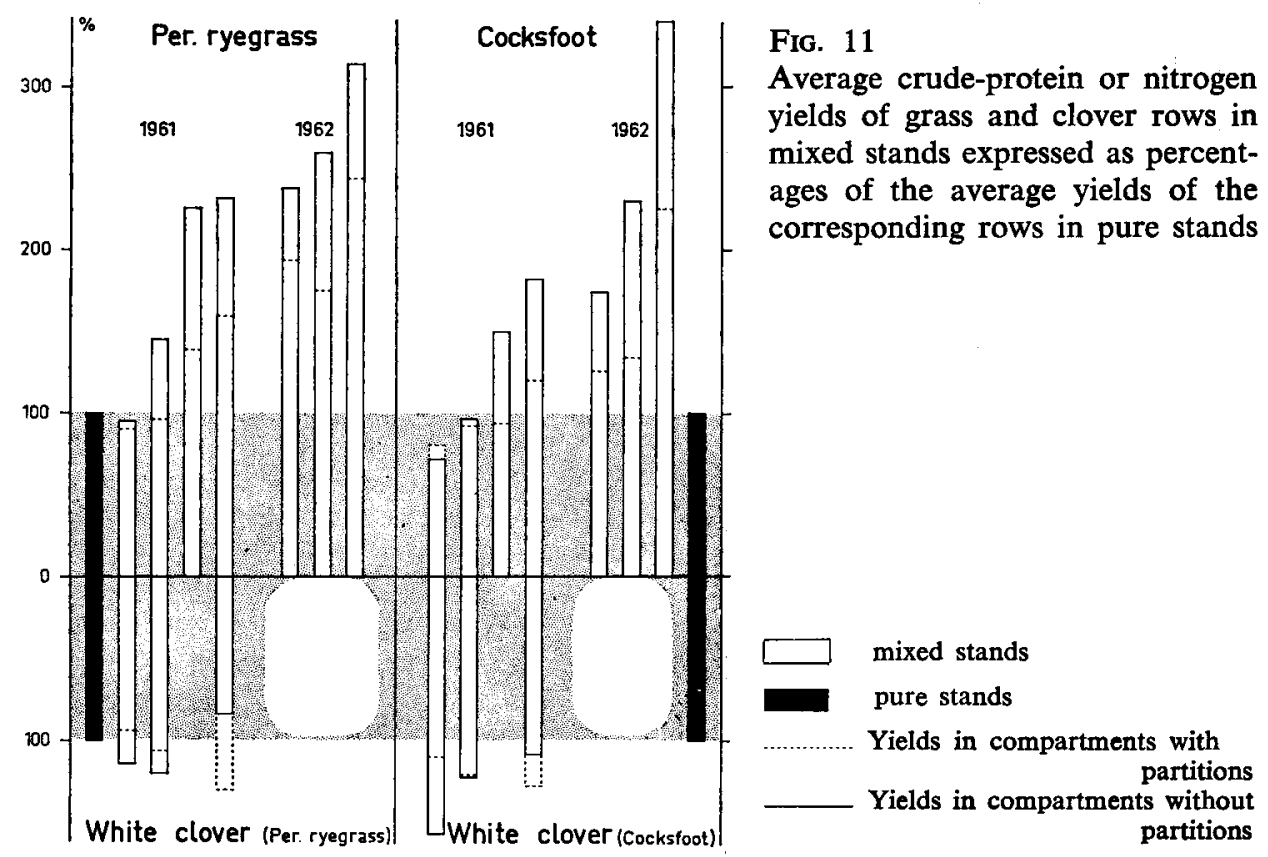




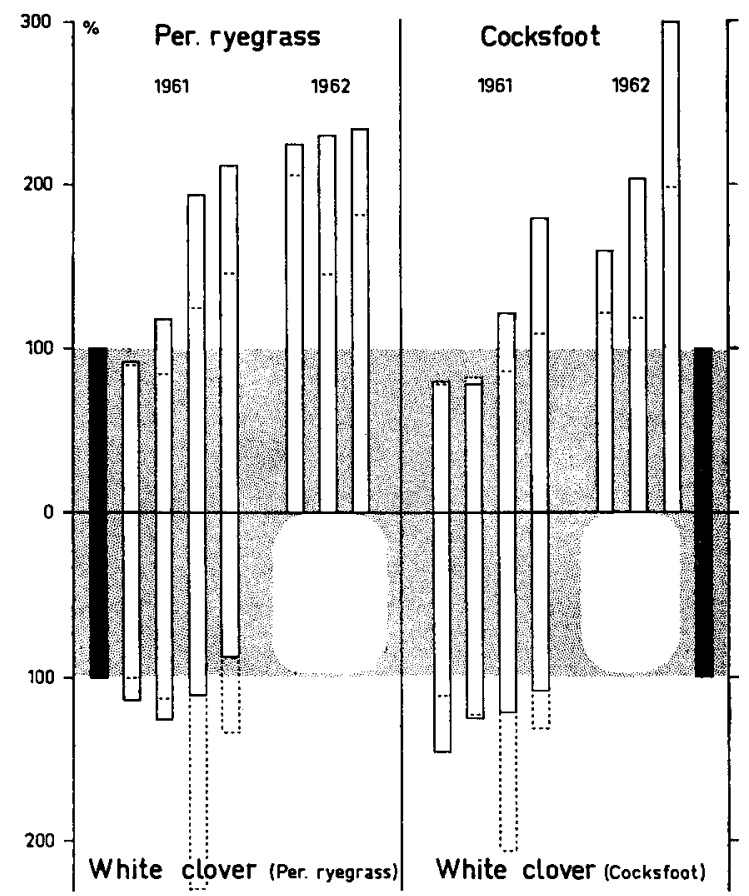

FIG. 12

Average dry-matter yields of grass and clover rows in mixed stands expressed as percentages of the average yields of the corresponding rows in pure stands

effects. In the first instance we cannot assume any linear relation between dry-matter production and nitrogen supply because with increasing nitrogen supply the dry-matter production reaches its maximum earlier than the nitrogen uptake. Secondly, the higher nitrogen content of grass in association with clover as compared with that of grass only (TABLE 8) prevents us from assuming a linear relation.

\section{Discussion of results}

\subsection{Crude protein}

\subsubsection{Differences between pure and mixed stands}

In FIG. 11 the dashed lines represent the crude-protein yield of the mixed stands in the compartments with partitions, the solid lines those in the compartments without partitions, both expressed as percentages of the pure stands.

As time went on grass in association with clover yielded considerably more than grass only (FIG. 5a and b, 6a and b). The representation in FIG. 11 suggests that this was due to certain favourable above-ground and underground influences of clover on grass in comparison with grass only, but it may be that onfavourable underground and above-ground effects of grass on grass suppressed the yield as compared with grass in association with clover. And perhaps it may be a combination of unfavourable influences of grass on grass and favourable influences of clover on grass.

The relatively higher yields of grass in association with clover occur in compartments with and without partitions, although in the latter case the increase occurred somewhat earlier and reached a higher level. In other words, the effect on the grass did 
not depend on the presence or absence of the partitions, but on the species of the adjacent rows.

An interpretation of the clover yields appears to be more complicated. The clover in a mixed culture yielded more than that in a pure stand, but after the second cut the regrowth of clover in all replicates was poor and irregular in both mixed and pure stands. However, the plots of pure clover were exceptionally poor in all compartments with partitions (FIG. 4). We will discuss this in chapter 4.2. The yields of the third cut are not recorded in TABLE 3 and FIG. 11 because the nitrogen content was not determined.

We may conclude that the protein yield of clover does not diverge so much as that of grass, but in general clover rows produced more protein in mixed stands. This was also observed by other investigators.

\subsubsection{Above-ground influences}

It can be seen from TABLE 3 and FIG. 11 that, when compared with the effects of grass on grass and expressed in terms of crude protein or nitrogen, the above-ground effects of clover on grass become highly significant, starting from the third cut of ryegrass and the fourth cut of cocksfoot, both in 1961. In spite of an abundant clover vegetation in 1962 (see FIG. 5b and 6b) grass yields per row in the mixed stands were $105,3 \%$ and $64,5 \%$ higher than in the pure stands of ryegrass and cocksfoot respectively.

Ryegrass benefited by the poor condition of the clover in the third cut in 1961 , but for cocksfoot it did not make much difference whether it stood between poor clover or in a pure stand, its growth at first being not so vigorous as the growth of ryegrass. From FIG. 11 it can be seen that only in the third cut of 1962 cocksfoot profited to about the same degree as ryegrass. This is in agreement with the opinion that cocksfoot is clover-tolerant in its youth, but gradually becomes more and more competitive to clover so that at last it may surpass ryegrass in this respect. This point was reached at the end of 1962 , both in compartments with and without partitions.

In the second cut of ryegrass and in the first and second cuts of cocksfoot, clover profited by above-ground factors to about the same degree when growing in association with grass as grass profited when growing in a pure stand. The complication attached to the clover after the second cut prevented us from drawing any conclusion, but it seems that in this case the clover is not so much influenced by aboveground factors as grass.

In the older sward the above-ground influences, especially when compared with the grass yields, played a more important role. These differences between grass in mixed and in pure stands may be due to: -

a. roots growing under the partitions,

b. above-ground effects.

The first possibility is ruled out because there were hardly any roots below a level of $60 \mathrm{~cm}$ (see TABLE 5) and these few roots did not grow under the plates into the clover soil. The clover roots even did not reach as far. The above-ground effects are the result of leaching of nitrogen by decaying clover leaves and petioles into the grass soil. This is illustrated by FIG. 13 and 14 in which the accumulation curves of nitrogen in grass were constructed for grass in association with clover and for grass only. This means that for compartments with partitions the yields given represent 
TABLE 5. Crop and root weights in $g$ dry matter of $3 / 4$ row of grass in pure and mixed stands with partitions at different depths in the summer of 1963

\begin{tabular}{|c|c|c|c|c|c|}
\hline \multirow{2}{*}{\multicolumn{2}{|c|}{$\begin{array}{l}\text { Root weights } \\
\text { at a depth of }\end{array}$}} & \multicolumn{2}{|c|}{ Per. ryegrass in between } & \multicolumn{2}{|c|}{ Cocksfoot in between } \\
\hline & & per, ryegrass & w. clover & cocksfoot & w. clover \\
\hline & crop yield : & 21.14 & 28.04 & 41.38 & 45.89 \\
\hline $\begin{array}{r}0-10 \mathrm{~cm} \\
10-28 \quad " \\
28-60 " \\
60 "\end{array}$ & $\begin{array}{l}\ldots \ldots \\
\ldots \ldots \\
\ldots \ldots \\
\ldots \ldots\end{array}$ & $\begin{array}{r}25.64 \\
6.44 \\
4.06 \\
0.76\end{array}$ & $\begin{array}{r}29.73 \\
8.90 \\
4.62 \\
0.38\end{array}$ & $\begin{array}{r}18.39 \\
4.79 \\
4.85 \\
0.24\end{array}$ & $\begin{array}{r}24.98 \\
4.16 \\
4.61 \\
0.56\end{array}$ \\
\hline
\end{tabular}

the quantity of nitrogen harvested in a grass row and taken up from the same quantity of soil, viz. 112.5 litres.

From the lines in FIG. 13 and 14 for compartments with partitions it is clear that in 1961 ryegrass and cocksfoot of mixed stands took up more nitrogen per row after the second and the third cuts from the same quantity of soil than ryegrass and cocksfoot in pure stands. It is even safe to say that the quantity was so great that in 1962 ryegrass in association with clover took up about twice as much nitrogen as ryegrass in pure stands.

We may also observe that ryegrass took up nitrogen far more effectively than cocksfoot.

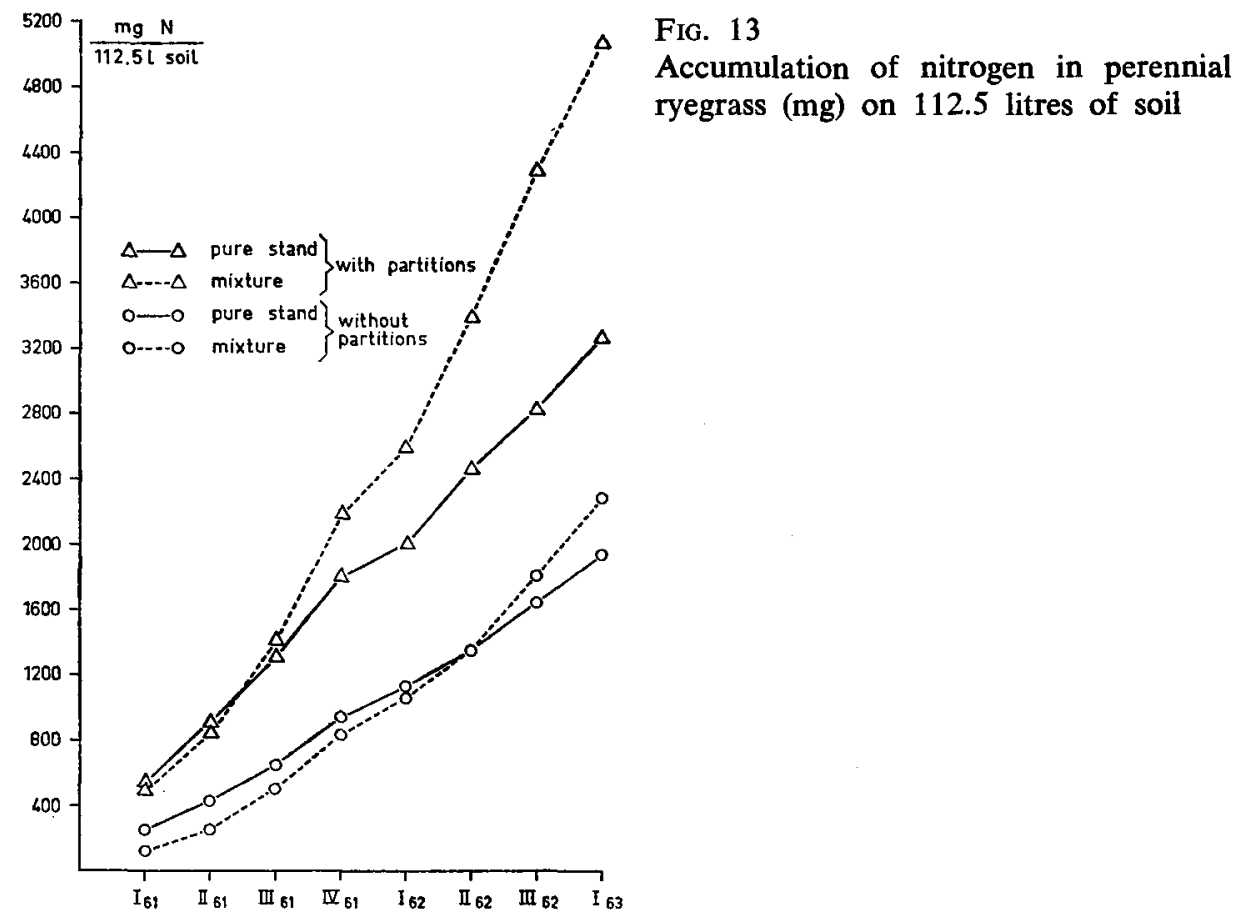

4.1.3. Underground influences

As we discussed in chapter 3 , the "per cent difference" is an estimate of the under- 


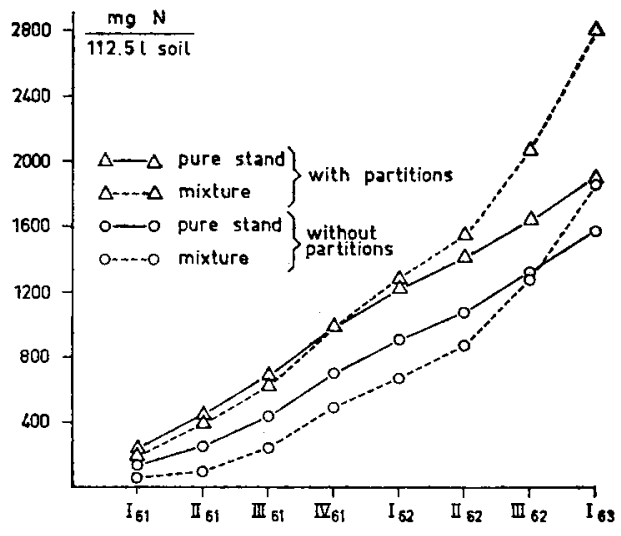

Frg. 14

Accumulation of nitrogen in cocksfoot (mg) on 112.5 litres of soil

ground nitrogen effect on the yields of mixed stands expressed as percentages of the nitrogen yields of pure stands. In FIG. 11 ryegrass and cocksfoot after the first and second cuts in 1961 show a beneficial and significant above-ground nitrogen effect of the associated growth of clover, increasing with time to $66-70 \%$ at the end of 1961 and to $68 \%$ (ryegrass) and $113 \%$ (cocksfoot) at the end of 1962 . At the same time in the compartments without partitions, the first two cuts of clover in mixed stands yielded significantly more nitrogen, and in three out of four cases this was due to the significant underground influence of the associated grass. Because of lack of further data we cannot conclude more about clover. To find out whether the beneficial underground influence of clover rows on grass rows is a consequence of clover nitrogen in FIG. 13 and 14 the nitrogen uptake by grass per unit of soil has been taken as representative of the nitrogen level of the soil.

We have already discussed the lines in the case of compartments with partitions in chapter 4.1.2. from which appears that the nitrogen accumulation in grass per unit of soil with partitions is considerably higher than without partitions.

This discrepancy in the monocultures may be totally due to the "plate factor" (see chapter 3), but in the mixed cultures this may also be ascribed to a less efficient utilization of the soil by the grass roots under grass and clover in compartments without partitions as compared with roots in the space restricted within plates.

In the compartments without partitions grass in mixed stands is more backward than grass in pure stands when only half the quantity of seed per unit of soil is sown. This is clearly demonstrated in FIG. 13 and 14 by the nitrogen yields of the first cut in 1961. Already after the second cut the lines of the mixed and the pure stands run parallel, which means that despite a start with different seed quantities, the uptake of nitrogen by the grass became equal in both the mixed and pure stands, probably through uptake of nitrogen from under the clover.

There are two factors which may have determined the further slope of the grass lines in the mixed cultures without partitions. First, the utilization of space under mixed stands by grass roots may be considered less efficient than in pure stands, which leads to a decrease of the slope of the line. Secondly, the utilization of clover nitrogen by grass in mixed stands leads to a further increase. Such a parallelism of the grass lines of the mixed and pure stands may be concluded from the equilibrium between these effects. But after the second cut in 1961 the positive effect of clover 
nitrogen seemed to dominate. The negative effect of a less efficient utilization of the rooting space by grass in mixed stands makes it impossible to compare the differences in nitrogen uptake per unit of soil in compartments with and without partitions, and thus to get an idea of the quantity of clover nitrogen by which grass profited when no partitions were present. To estimate these profits more exactly a similar experiment was set up in 1962 in which grass and clover were included at different spacings. DE WIT's interpretation of the results gives a better approximation of the nitrogen profits of grass caused by clover, as described in the next chapter.

\subsubsection{The crude-protein results worked out by the competition theory}

The results of the three years are represented in the competition diagrams of crude protein and relative seed frequency in FIG. 15. The yields of the seed frequencies $1.0,0.67,0.50$ and 0.33 are given as averages of $9,4,8$ and 2 replicates respectively. Hence, in the following treatment the greatest importance is attached to the data for the relative seed frequencies of 1.0 and 0.5 .

The value of the relative crowding coefficients was estimated in all diagrams where the yield curves are increasing functions of the relative seed frequencies. These values are given in TABLE 6 and the corresponding yield curves calculated according to equation (1) are shown in FIG. 15. From the $K_{g c}$-values of TABLE 6 and from the crude-protein diagrams of FIG. 15 we may conclude that in the compartments with and without partitions the competitive power of the grass (ryegrass as well as cocksfoot) increases with time, whereas cocksfoot shows this increment a little later than ryegrass. This is in agreement with the statement in chapter 4.1.2. that cocksfoot is probably clover-tolerant in its youth, but gradually becomes more competitive to clover. Besides this, the curves and also the $\mathbf{K}_{\mathrm{gc}}$ - values indicate that in unseparated root systems the competitive power of the grass was considerably higher than in separated root systems.

The diagrams of the first two cuts in 1961 of the compartments with partitions give a normal picture of two plant species competing for the same "space" and not af-

TABLE 6. The values of the relative crowding coefficients of the crude-protein yields of grass and clover and their products

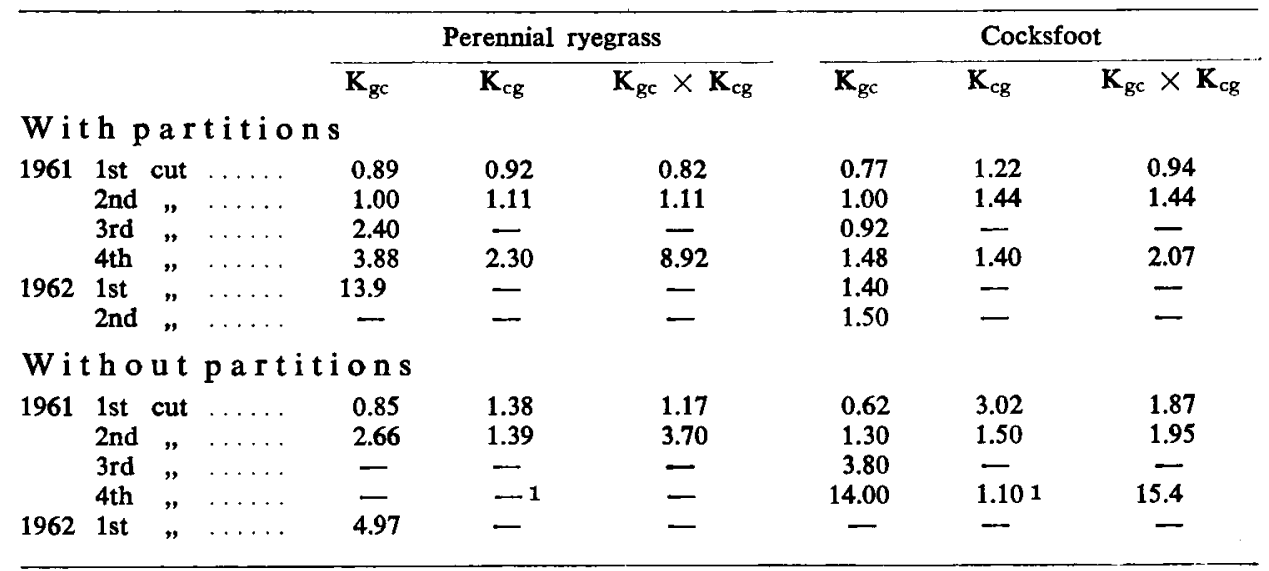

1 Calculated from the yields at the seed frequencies 0.33 and 0.66 . 
官
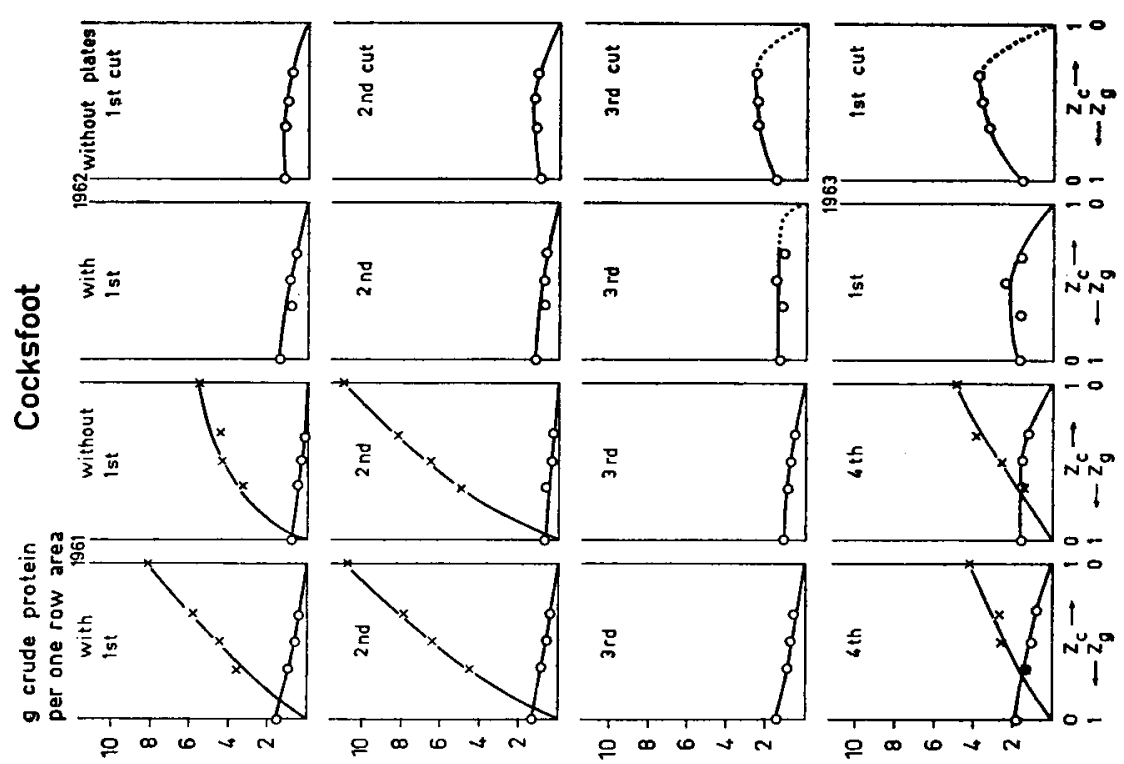

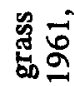

फै.
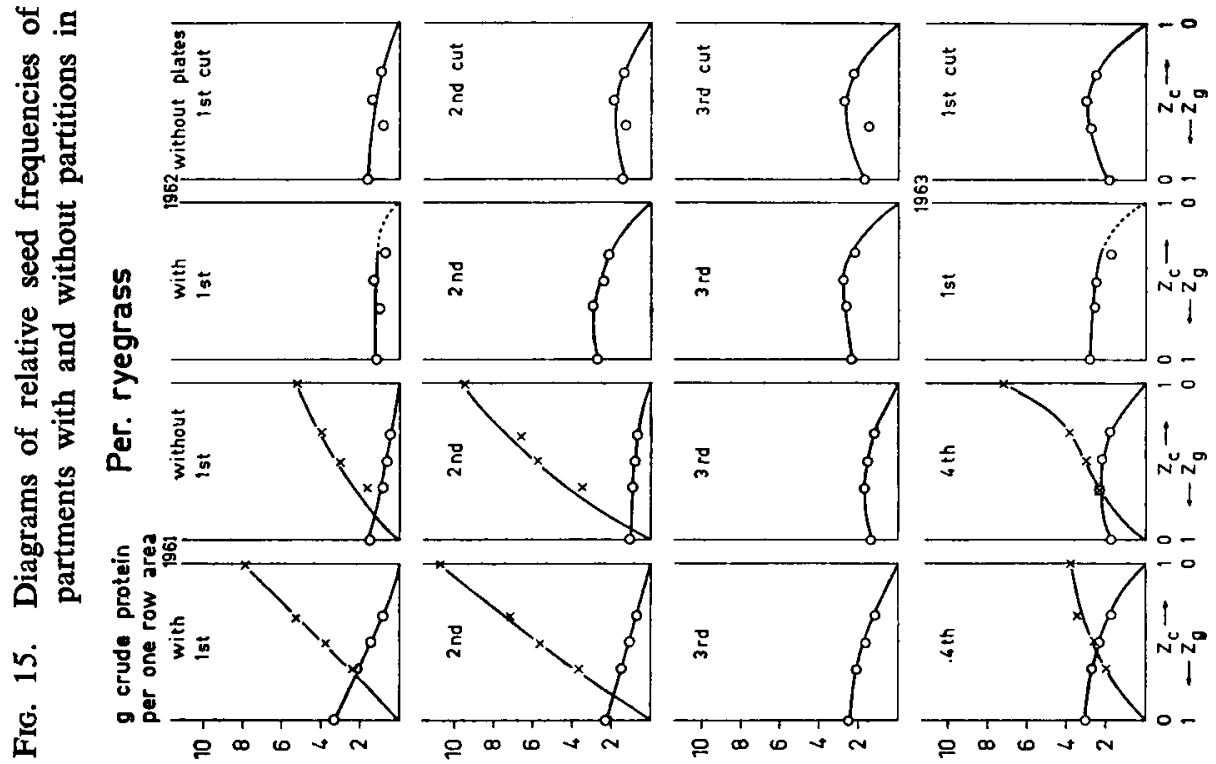
fecting each other in any other way so that $\mathrm{K}_{\mathrm{gc}} \times \mathrm{K}_{\mathrm{cg}}=1$ (MODELS I and II, chapter 2). In unseparated root systems the product of $\mathrm{K}_{\mathrm{gc}} \times \mathrm{K}_{\mathrm{cg}}$ in the first and second cut is mostly larger than 1 (MODELS III and V), which indicates that some extra space must have been occupied. The difference in competition between compartments with and without partitions may be explained as follows: - With or without partitions, clover has a supply of extra nitrogen from its rhizobial nitrogen fixation as follows from the high protein yield of monoculture clover compared with monoculture grass.

During the growth of the first two cuts in compartments with partitions the grass neither profited from $\mathbf{N}$ in the soil below the clover nor from $\mathbf{N}$ fixed by the clover. In the compartments without partitions, where $\mathrm{K}_{\mathrm{gc}} \times \mathrm{K}_{\mathrm{cg}}$ exceeds 1 in three out of four cases, not only clover attained its own nitrogen space, but at the same time grass took up some soil nitrogen from under the clover. This was prevented by the plates of the compartments with partitions.

The crude-protein figures of clover of the third cut are not available. The diagrams of the fourth cut with partitions correspond with MODEL III, which is due to rhizobial nitrogen fixation. The diagram of ryegrass in the compartments without partitions corresponds with MODEL V, which is due to clover nitrogen taken up by the grass.

From the grass lines it is concluded that also in 1962 grass profited from clover nitrogen either from excretion of nitrogen by the clover roots into the soil or from nitrogen of decaying leaves, petioles, roots and nodules.

To decide to what extent clover fixes nitrogen in association with grass, we calculated the gain of nitrogen in the mixed stands compared with that of the pure grass stands in the same compartments without partitions (TABLE 7). To account for the amount of nitrogen in the roots, we multiplied the nitrogen content of the cut parts

TABLE 7. Nitrogen fixation and benefit of grass by clover in an association of alternate grass and clover rows at distances of $15 \mathrm{~cm}$, expressed as $\mathrm{kg} \mathrm{N}$ per ha

Fixation on a field with alternate rows of clover and perennial ryegrass or cocksfoot

\begin{tabular}{llccc} 
& \multicolumn{3}{c}{ Fixation on a field with alternate rows of clover and perennial ryegrass or cocksfoot } \\
\cline { 3 - 4 } 1961 1st cut & $\ldots \ldots \ldots \ldots \ldots$ & per. ryegrass & cocksfoot \\
2nd $"$ & $\ldots \ldots \ldots \ldots \ldots$ & 23.8 & 41.6 \\
3rd $"$ & $\ldots \ldots \ldots \ldots \ldots$ & 60.9 & 68.6 \\
4th $"$ & $\ldots \ldots \ldots \ldots \ldots$ & 28.9 & 22.7 \\
Total 1961 & $\ldots \ldots \ldots \ldots \ldots$ & 37.8 & 28.3 \\
\hline
\end{tabular}

of grass by $3 / 2$, and that of clover by $5 / 4$, which ratios were obtained from literature. The ultimate figure is still rather low, because the fixed nitrogen leached from the soil and taken up by micro-organisms or left in the soil was not taken into account.

The crude-protein content of clover of the 3rd cut was not determined, but estimated at about $25 \%$ (TABLE 8). The uptake of nitrogen by clover in 1962 could not be estimated because neither yields nor $\mathrm{N}$-contents were known.

An estimate of the amount by which grass profited from clover can be obtained by calculations based on the competition theory appllied to MODEL V. The nitrogen yields of the last cut of clover and perennial ryegrass in 1961 on the plots without partitions have also been shown in FIG. 16a. A comparison with the dry-matter yields of 


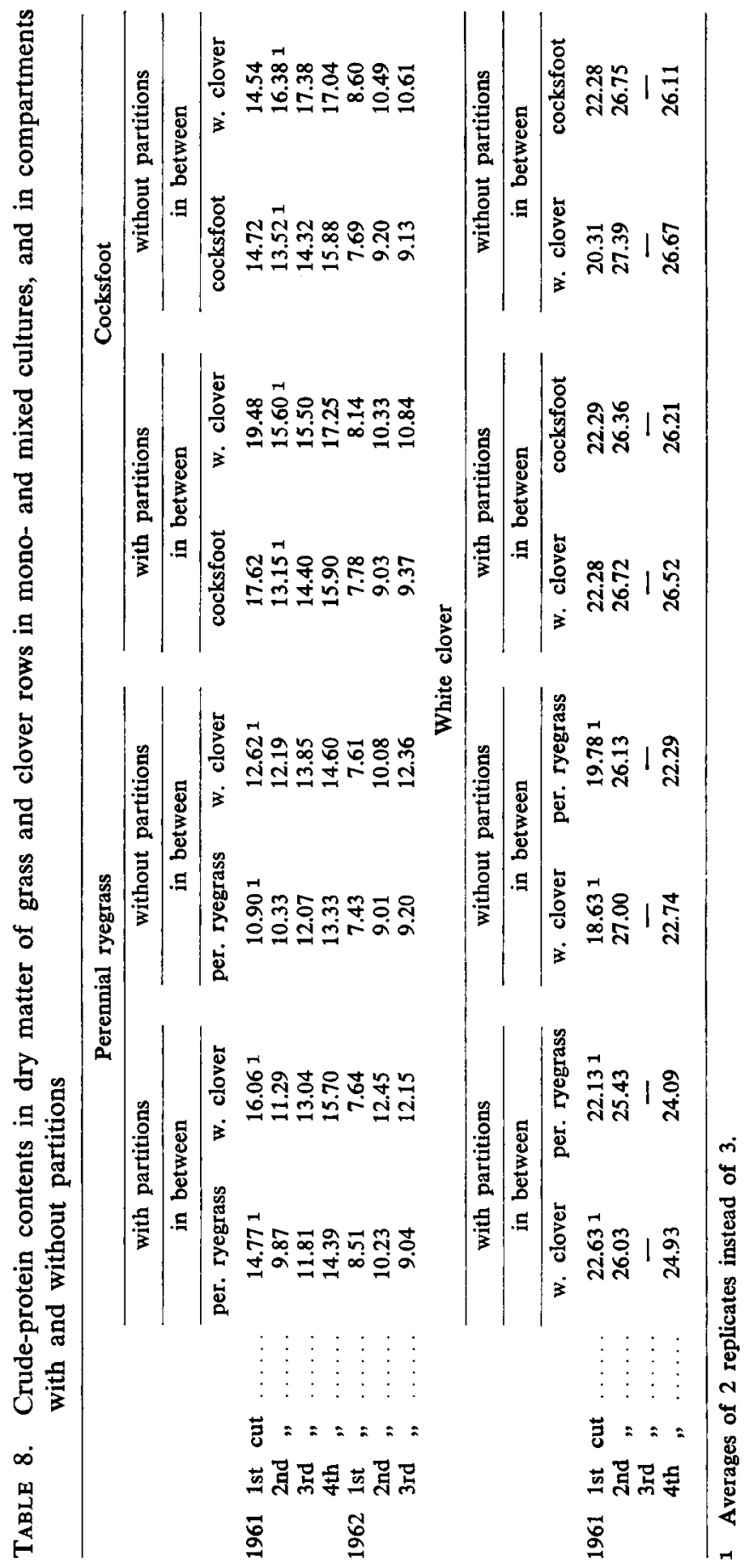


the third cut shows that the S-shape of the clover curve is genuine, so that the data are in agreement with MODEL V. By means of equation (2) it is now possible to calculate the relation between the relative seed frequency of clover and the relative crowding coefficient of clover as compared with grass $\left(\mathrm{K}_{\mathrm{cg}}\right)$. This relation is shown in FIG. 16b. During the first harvests MODEL II appeared to be applicable, which indicates that as long as nitrogen fixation does not interfere with the product of the

FIG. 16a. Replacement diagram for the fourth cut in 1961 of clover and perennial ryegrass in the compartments without partitions

b. Relation between the relative seed frequency of clover and the relative crowding coefficients used for the calculations

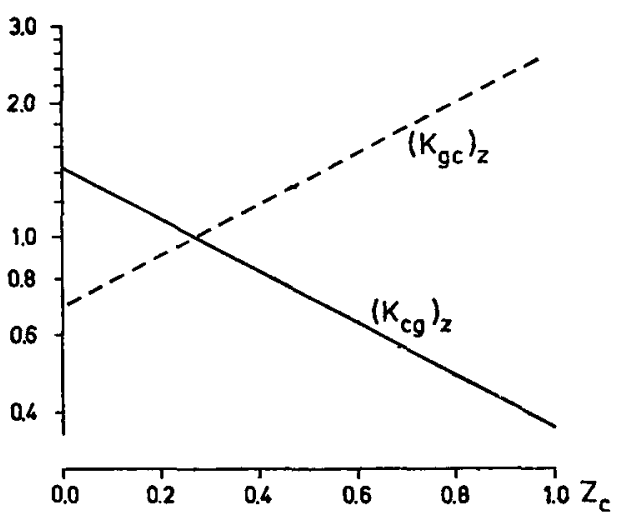

a

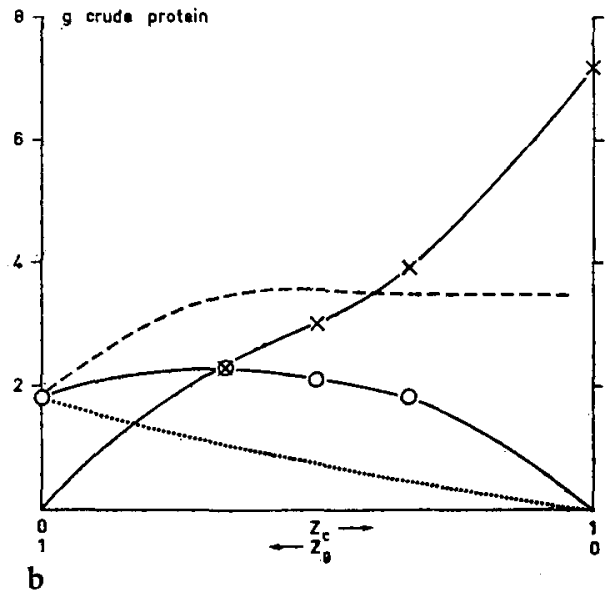

Yield of monoculture grass calculated assuming that the nutrition level is the same as in the mixture.

Yield of grass in the mixture, calculated assuming that the grass does not profit from the clover.

relative crowding coefficient of grass (with respect to clover) and of clover (with respect to grass) which is 1 . Hence, we may accept that the value of $c=\left(K_{c g}\right)_{z} \times$ $\left(K_{\mathrm{gc}}\right)_{\mathrm{z}}$ equals 1 , so that the dashed line which is a representation of the solid line in FIG. $16 \mathrm{~b}$ represents the value of $\mathrm{K}_{\mathrm{gc}}$ at different seed frequencies. By means of this curve it is possible to calculate two important yield relations. By applying equation (3) for instance it is possible to calculate the yield of a pure stand of grass at a same nutrient level as that of grass in association with clover. The result is shown by the dashed line. The yield does not increase after a relative seed frequency of clover of 0.3 onwards. As the percentage of crude protein of the grass is only $15 \%$ this indicates that the grass does not fully benefit from its association with clover. This may be due to the arrangement of clover and grass in rows.

The relative crowding coefficient of grass as compared with clover at a clover frequency of zero is about 0.7 (FIG. 16b). This relative crowding coefficient would have occurred throughout the whole frequency range if the grass did not profit at all from the clover. Hence, under such conditions the protein yield of grass in association with clover can be calculated by substituting 0.7 for $\mathrm{K}$ and $1.8 \mathrm{~g} \mathrm{~N}$ for $\mathrm{M}$ (the 
yield of the monoculture) in equation 1 . The result is shown by the dotted line in FIG. 16a. The difference between this curve and the original curve of grass gives the amounts by which grass profited from clover at all seed frequencies.

The higher nitrogen yields of grass rows in mixed stands as compared with grass rows in pure stands may be caused by either a higher dry-matter yield or a higher protein content or by both. TABLE 8 shows that there is a considerable difference in nitrogen content in favour of the grass in mixed stands in compartments with and without partitions. This is a consequence of nitrogen depletion in the grass of pure stands. At the same time we may observe from TABLE 8 that in the second and fourth cuts the crude-protein content of clover in association with grass is always slightly lower than that of clover only.

\subsection{D r y m a t ter}

The yields and competitive power in TABLE 4 and FIG. 12 are shown in the same way as in TABLE 3 and FIG 11, except that TABLE 4 and FIG. 12 refer to dry matter and not to crude protein. The differences between the dry-matter yields in FIG. 12 and the crude-protein yields in FIG. 11 are not essential at all. Only the level of the relative protein yields of grass in mixed stands is higher than that of dry matter. There is hardly any difference between the competition diagrams in FIG. 15 and 17. Any slight difference in protein content of the grass in mixed and pure stands usually causes the relative crowding coefficient $\mathrm{K}_{\mathrm{gc}}$ to be lower for dry matter than for protein (TABLE 9).

TABLE 9. The values of the relative crowding coefficients of grass compared with clover $\left(\mathrm{K}_{\mathrm{gc}}\right)$ and of clover compared with grass $\left(\mathrm{K}_{\mathrm{cg}}\right)$ and their products for the dry matter in the cuts in 1961 and 1962

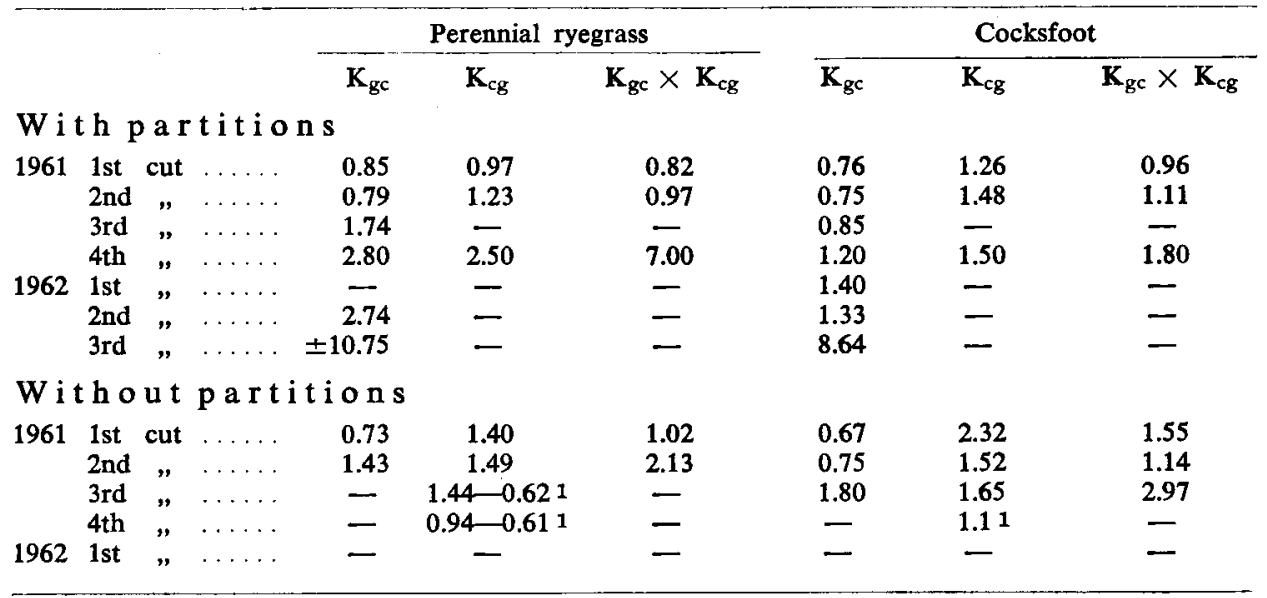

1 Calculated from the yields at the seed frequencies 0.33 and 0.66 .

For the third cut in 1961 in the compartments with partitions (FIG. 17) we see a deviating clover line with relatively low yield values at $z_{c} 0.67$ and 1.00. There are two ways to account for it: - first, we may consider this as a coincidence for which no explanation can be given; secondly, we may consider this phenomenon as a consequence of certain regularities. The first solution has little to recommend it, because 
SOME EFFECTS OF ASSOCIATED GROWTH ON GRASS AND CLOVER UNDER FIELD CONDITIONS

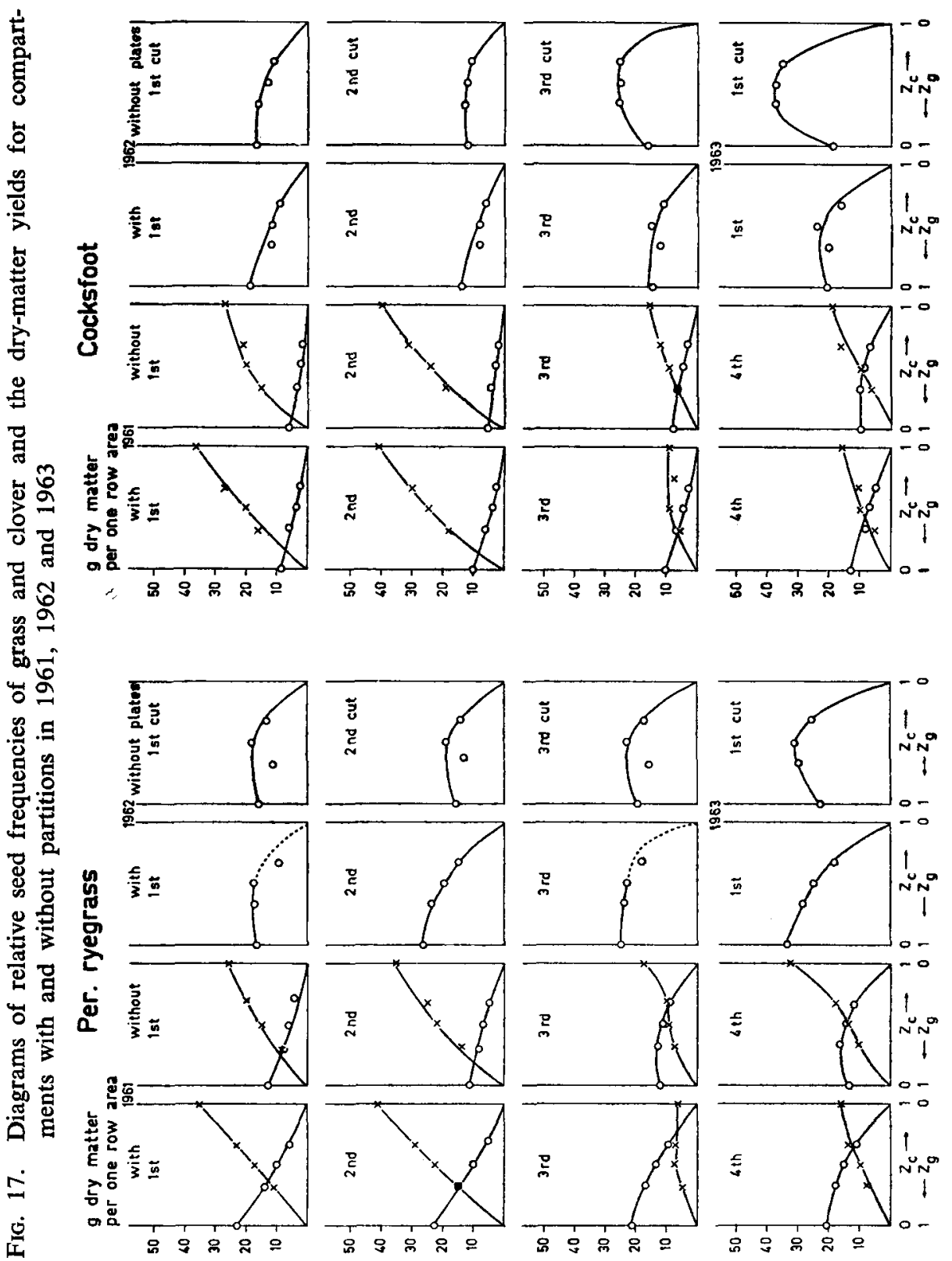


ryegrass and cocksfoot showed this phenomenon in every replicate as appears from TABLE 10. Moreover ENNIK (1960) found the same in his pots under a low light intensity. This confirms our observations that it is not a question of extra high yields at $\mathrm{z}_{\mathrm{c}}$ equal to 0.5 , but of extra low yields at $\mathrm{z}_{\mathrm{c}}$ equal to 1.0 .

TABLE 10. Average dry-matter yields in $g$ of clover rows in pure and mixed stands in the third cut of 1961 in the compartments with and without partitions

\begin{tabular}{|c|c|c|c|c|c|c|}
\hline & \multicolumn{3}{|c|}{ Perennial ryegrass } & \multicolumn{3}{|c|}{ Cocksfoot } \\
\hline Replicate : & I & II & III & I & II & III \\
\hline \multicolumn{7}{|l|}{ Pure stand } \\
\hline with partitions & 5.8 & 9.4 & 3.9 & 11.4 & 4.7 & 10.9 \\
\hline without partitions & 16.1 & 20.4 & 15.1 & 19.5 & 10.4 & 16.6 \\
\hline \multicolumn{7}{|l|}{ Mixed stand } \\
\hline with partitions & 17.5 & 13.8 & 13.1 & 21.5 & 10.8 & 21.1 \\
\hline
\end{tabular}

The question arises why the yield depression did not occur in the compartments without partitions. We have not yet been able to explain this phenomenon, but in the future we hope to give a reasonable interpretation after having carried out pot experiments under controlled conditions.

It is important to know whether a mixed grass/clover stand yields more or less than: -

a. a pure stand of either grass or clover on the same area;

b. the average yield of the pure stands of grass and clover.

a. The average dry-matter yields of mixed stands and of clover only are compared with the corresponding stands of grass only in FIG. 18. In this soil, which is also deficient in nitrogen, the clover yields exceed the grass yields by far, in particular those of cocksfoot. The mixed stands yielded more than the pure stands of grass, but less than the pure stands of clover.

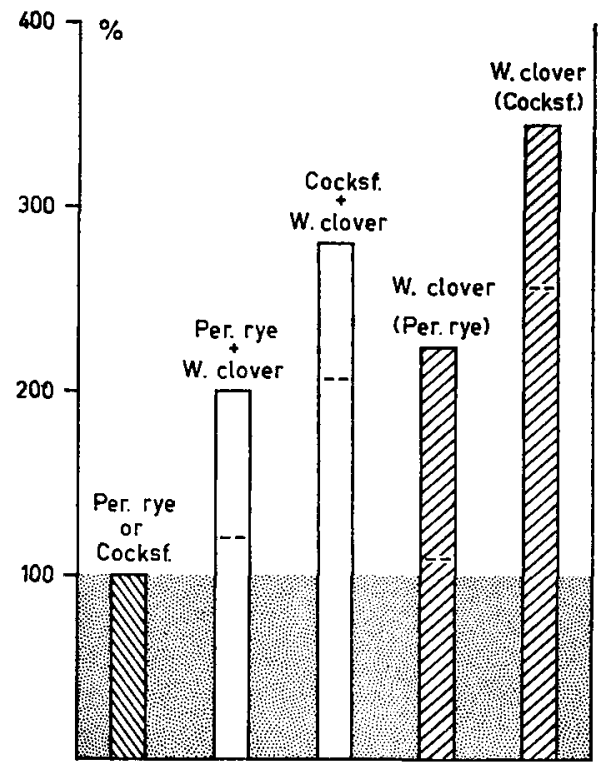

FIG. 18

Average dry-matter yields in 1961 of mixed stands and of pure clover stands expressed as percentages of the corresponding pure grass stands on the same area

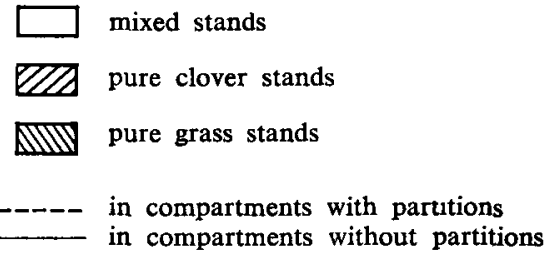

Neth. J. agric. Sci., Vol. 13 (1965) No. 3 (August) 

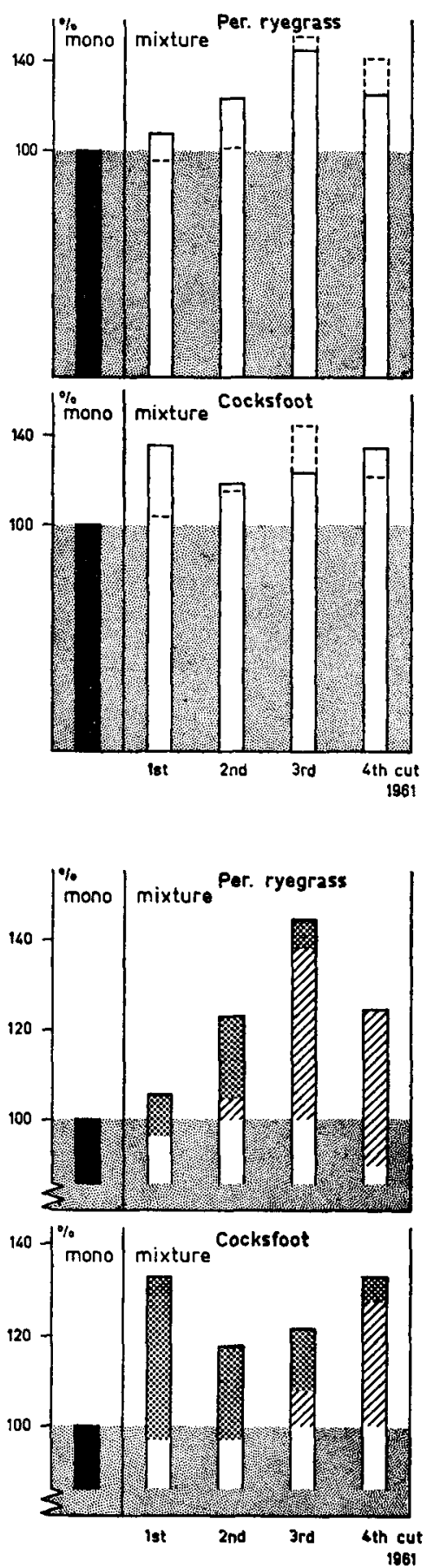

FIG. 19

Average dry-matter yields of one row of clover + one row of grass in mixed stands expressed as percentages of the corresponding sum of yields in pure stands
FIG. 20

Extra yields of FIG. 19
器到 white clover grass 
b. In FIG. 19 the average dry-matter yields of one row of clover and one row of grass in mixed stands are compared with those in pure stands for each cut in 1961. In all cuts, even in the first, the yields of the mixed stands in the compartments without partitions expressed as percentages of the pure stands were the highest. Considering the four cuts in 1961, it can be seen that the extra yield approximated to $24 \%$; in the last cuts this was largely due to above-ground influences.

In FIG. 20 is indicated to what degree these extra yields obtained by cultivating grass and clover together, were induced by a better growth of each of the associates. Initially these extra yields were mainly due to an increased clover growth, but in the third and fourth cuts of ryegrass and in the fourth cut of cocksfoot the extra yields were mainly due to an increase in grass yields. This figure also demonstrates that ryegrass becomes competitive to clover at an earlier stage than cocksfoot.

\section{Conclusions}

The above description of a two-year field experiment with pure grass, pure clover, alternate grass and clover rows and separated and unseparated root systems on a nitrogen-deficient soil, leads us to draw the following conclusions: -

The general picture of the dry-matter yields of grass in association with clover in comparison with grass only (FIG. 12) was practically true for both the compartments with and without partitions, only the yields of compartments without partitions being higher than those with partitions. This means that the development based on the relative yields of the grass depended upon underground as well as on above-ground influences. The general pattern of the crude-protein yields of grass in association with clover as compared with those of grass only (FIG. 11) was nearly the same as that of the dry-matter yields.

The crude-protein contents in the dry matter of grass in mixed stands were higher than those of grass in pure stands as the figures in TABLE 8 demonstrate.

In the mixed stands of grass and white clover especially the grass component had undergone above-ground and underground influences from the clover as compared with pure stands.

We had to account for considerable above-ground influences: - in the first two cuts of 1961 of ryegrass and in the first three cuts of cocksfoot, grass only yielded more than grass in association with clover. In the next cuts the grass benefited increasingly and significantly from the clover. For 1962 this amounted to $46 \%$ (cocksfoot) and $74 \%$ (ryegrass) of the dry-matter yield of pure grass and $65 \%$ (cocksfoot) and $105 \%$ (ryegrass) of the crude-protein yield of pure grass. The above-ground influences of clover on grass which may be seen as a result of nitrogen leached by decaying clover leaves and petioles, resulted in a higher nitrogen uptake by grass rows in mixed stands on the same quantity of soil. Cocksfoot took up this nitrogen far less effectively than ryegrass (FIG. 13 and 14).

Ryegrass after the first cut and cocksfoot after the second cut in 1961 showed a beneficial and significant underground nitrogen effect by the associated growth of clover, increasing with time to $64-74 \%$ at the end of 1961 and to $68 \%$ (ryegrass) and $113 \%$ (cocksfoot) of the nitrogen yield in pure grass at the end of 1962. At the same time clover was not so much influenced by the adjacent vegetation as grass. The few clover data do not give sufficient information, but in general clover in association with grass yielded slightly more than clover only. 
The crude-protein contents of the dry matter of clover in mixed stands were mostly slightly lower than those of clover in pure stands (TABLE 8).

We have to reckon with a particular influence of the partitions on plant growth when we carry out experiments like these. This influence may cause grass in pure stands to take up considerably more nitrogen per unit of soil than in compartments without partitions (FIG. 13 and 14). The influence may depend on the kind of soil.

Mixed stands of grass and clover in 1961 yielded considerably more than pure grass stands on the same area, but less than pure stands of clover (FIG. 18).

In all 1961 cuts the yields of the mixed stands in the compartments without partitions were higher than the average of the pure stands of grass and clover (FIG. 19). Initially these extra yields of the mixed stands have been mainly obtained by increased clover growth. In the third and fourth cut of ryegrass and in the fourth cut of cocksfoot the extra yields were mainly due to increased grass growth (FIG. 20).

From DE WIT's competition theory we may conclude that the competitive power of the grass, increasing with time, ultimately gave better results in unseparated than in separated root systems (FIG. 15 and 17). From the values of the relative crowding coefficients (TABLES 6 and 9) and from the competition diagrams (FIG. 15 and 17) we may conclude that in compartments with and without partitions ryegrass is initially more competitive to clover than cocksfoot, but at the end of 1962 this difference in competitive behaviour had fully disappeared. This experiment led to the development of a new model of competition diagram in the case where grass in association with clover competes better because of uptake of nitrogen produced by the clover (MODEL V). In the year of establishment the quantity of nitrogen fixed by clover at a seed frequency of 0.50 in above-ground and underground parts of the plants amounted to about $150-160 \mathrm{~kg} \mathrm{~N} / \mathrm{ha}$ (TABLE 7).

With the data available we cannot determine the origin of the clover nitrogen; perhaps it comes from excretion by clover roots and nodules, perhaps from decaying roots and nodules, petioles and leaves.

\section{ACKNOWLEDGEMENTS}

The authors would like to thank Ir. A. M. J. VAN MONTfORT (Department of Mathematics, Agricultural University, Wageningen) who advised us on the analyses of variance, Prof. Ir. M. L. 'T HART (head of the Department of Field Crops and Grassland Husbandry, Agricultural University, Wageningen) who stimulated this work and gave critical comment on the manuscript, Dr. Ir. C. T. DE WrT (I.B.S., Wageningen) who developed part of the theory and provided many critical observations, Miss Dr. J. RuINEN (Department of Microbiology, Agricultural University, Wageningen) who made some valuable suggestions and Mr. G. Franken (I.V.P., Wageningen) who revised the text.

\section{REFERENCES}

Áberg, E., I. J. Johnson and C. P. WILsIE

Allos, H. F., and W. V. BARTHOLOMEW and

ARENS, $\mathrm{K}$.
1943 Associations between species of grasses and legumes. J. Am. Soc. Agron. 35, 357-369.

1955 Effect of available nitrogen on symbiotic fixation. Proc. Soil Sci. Soc. Am. 19, 182-184.

1959 Replacement of symbiotic fixation by available nitrogen. Soil Sci. 87, 61-66.

1934 Die kutikuläre Exkretion des Laubblattes. Jb. wiss. Bot. 80, 248-300. 
BathuRst, N. O., and

K. J. MitChelL

BERGH, J. P. VAN DEN, and 1960 C. T. DE WIT

BLACK, C. A.

Bond, G., and J. Boyes

Brockman, J. S., and K. M. Wolton

BRYAN, W. W.

Burton, G. W., J. E. JACKSON and F. E. KuOSE

Butler, G. W., and

N. O. BathuRst

Butler, G. W., R. M. Greenwood and KATHLEEN SOPER

Chamblee, D. S.

Chapman, H. D.

Cowling, D. W.

Davies, R. O., T. B. Morgan and W. Ellis Davies

DiLz, K., and E. G. Mulder

Donald, C. M.

ENGEL, H., und

M. ROBERG

ENNIK, G. C.

GIöBEL, G.

Herriot, J. B. D., and D. A. Wells and J. DiLnot

HollidaY, R., and D. Wilman

Holmes, W., and D. S. MACLuSKY
1958 The effect of light and temperature on the chemical composition of pasture plants. N.Z. J. Agric. Res. 1, 540-552.

Concurrentie tussen timothee (Phleum pratense L.) en reukgras (Anthoxantum odoratum L.). Jaarb. I.B.S., 155-166.

1957 Soil-Plant Relationships. 332 pp.

1939 Excretion of nitrogenous substances from root nodules: observations on various leguminous plants. Ann. Bot. N.S. 3, $901-914$.

1963 The use of nitrogen on grass/white clover swards. J. Br. Grassl. Soc. 18, 7-13.

1962 The role of the legume in legume/grass pastures. Comm. W. Bur. of Past. Field Cr. Bull. No. 46, 147-160.

1959 The influence of light reduction upon the production, persistence and chemical composition of Coastal Bermuda grass, Cynodon Dactylon. Agron. J. 51, 537-542.

1956 The underground transference of nitrogen from clover to associated grass. 7th Intern. Grassl. Congr. 168-178.

1959 Effects of shading and defoliation on the turnover of root and nodule tissue of plants of Trifolium repens, Trifolium pratense and Lotus uliginosus. N.Z. J. Agric. Res. 2, 415-426.

1958 Some above- and below-ground relationships of an alfalfaorchardgrass mixture. Agron. J. 50, 434-437.

1943 Failure of vetch to excrete nitrogen from the nodules when grown in association with nitrogen-deficient citrus seedlings. J. A.m Soc. Agron. 35, 635-637.

1961 The effect of white clover and nitrogenous fertilizers on the production of a sward. J. Br. Grassl. Soc. 16, 281-290.

1953 The yields and composition of lucerne, grass and clover under different systems of management. J. Br. Grassl. Soc. 8, 149-168.

1962 Effect of associated growth on yield and nitrogen content of legume and grass plants. Pl. Soil. 16, 229-237.

1963 Competition among crop and pasture plants. Adv. Agron. 15, $1-118$.

1938 Die Stickstoffausscheidung der Würzelknöllchen. Ber. dt. bot. Ges. 56, 337-352.

1960 De concurrentie tussen witte klaver en Engels raaigras bij verschillen in lichtintensiteit en vochtvoorziening. Jaarb. I.B.S., $37-50$

1926 The relation of the soil nitrogen to nodule development and fixation of nitrogen by certain legumes. N. J. agric. Exp. Sta. Bull. No. 436, 125 pp.

1960 Clover nitrogen and sward productivity. J. Br. Grassl. Soc. $15,63-73$.

1959 The grazing animal and sward productivity. J. Br. Grassl. Soc. 14, 191-198.

1962 The effect of white clover, fertilizer nitrogen and simulated animal residues on yield of grassland herbage. J. Br. Grassl. Soc. 17, 206-213.

1955 The intensive production of herbage for crop-drying. Part VI : A study of the effect of intensive nitrogen fertilizer treatment on species and strains of grass, grown alone and with white clover. J. agric. Sci. 46, 267-286. 
JOHNSTONE-

Wallace, D. B.

JULEN, G., and

K. WIKLUND

KILCHER, M. R., and

D. H. HeInRIChs

KLAPP, E.

LAUSBERG, ThUSNELDA

LIPMAN, J. G.

Ludwig, C. A., and F. E. Allison

LYoN, T. L., and

J. A. Bizzell

Mac Anliffe, C.,

D. S. Chamble et al.

Mac Cloud, D. E., and G. O. MorT

MADHOK, M. R.

MelVILle, J., and

P. D. Sears

MYeRs, H. G.

Nowotnowna, ANNa

Pritchett, W. L., and L. B. Nelson

RoberTs, J. L., and F. R. Olson

ROBERTS, R. H.

RuSSELl, E. J.

SChEYgrond, W., H. Vos and A. SONNEVELD

SCHREVEN, D. A. VAN

SMITH, C. A.

SNEDECOR, G. W.

SONNEVELD, A., and W. SCHEYGROND

Stallings, J. H.

STEWART, I., and F. E. BEAR

Strong, T. H., and H. C. Trumble
1937 The influence of grazing management and plant association on the chemical composition of pasture plants. J. Am. Soc. Agron. 29, 441-455.

1955 Effect of irrigation and shadowing on the content of crude protein, crude fibre and carotene in some forage plants. Sver. Utsädestör. Tidskr. 65, 357-381.

1958 The performance of three grasses when grown alone, in mixture with alfalfa and in alternate rows with alfalfa. Can. J. Pl. Sci. 38, 252-259.

1954 Wiesen und Weiden. 519 pp.

1935 Quantitative Untersuchung über die kutikuläre Exkretion des Laubblattes. Jb. wiss. Bot. 81, 769-806.

1912 The associative growth of legumes and non-legumes. $N$. $J$. agric. Exp. Sta. Bull. No. 253, 1-48.

1940 Further experiments concerning diffusion of nitrogenous compounds from healthy legume nodules or roots. Am. J. Bot. 27, 719-725.

1911 A heretofore unnoted benefit from the growth of legumes. Cornell Univ. agric. Exp. Stat. Bull. No. 294, 365-374.

1953 Influence of inorganic nitrogen on nitrogen fixation by legumes as revealed by $\mathbf{N}^{15}$. Agron. J. 50, 334-337.

1958 Influence of association upon the forage yield of legume-grass mixtures. Agron. J. 45, 61-65.

1940 Association of legumes and non-legumes. Soil Sci. 49, 419-431.

1953 Pasture growth and soil fertility. II. The influence of red and white clovers, superphosphate, lime and dung and urine on the chemical composition of pasture. N.Z. J. Sci. Technol. 35, Sec. A., $30-41$.

1945 Excretion of nitrogen compounds by some legumes grown in sand culture. J. Am. Soc. Agron. 37, 81-89.

1937 An investigation of nitrogen uptake in mixed crops not receiving nitrogenous manure. J. Agric. Sci. 27, 503-510.

1951 The effect of light intensity on the growth characteristics of alfalfa and brome grass. Agron. J. 43, 171-177.

1942 Interrelationships of legumes and grasses grown in association. J. Am. Soc. Agron. 34, 695-701.

1946 Effect of temperature and photoperiod upon growth of grasses planted with legumes. J. Am. Soc. Agron. 38, 947-953.

1953 Soil Conditions and Plant Growth. 635 pp.

1958 Witte klaver in kunstweiden. Kali. IV, 219-225.

1959 Effects of added sugars and nitrogen on nodulation of legumes. Pl. Soil. 11, 93-112.

1962 Tropical grass/legume pastures in Northern Rhodesia. J. Agric. Sci. 59, 111-118.

1959 Statistical Methods. 534 pp.

1954 De invloed van witte klaver op de opbrengst van kunstweiden in de zomer. Versl. C.I.L.O. 83-90.

1926 The form of legume nitrogen assimilated by non-legumes when grown in association. Soil Sci. 21, 253-276.

1951 Ladino clover - its mineral requirements and chemical composition. N. J. agric. Exp. Sta. Bull. No. 759, 1-32.

1939 Excretion of nitrogen by leguminous plants. Nature. 143, 286-287. 
Tewari, G. P., and A. R. SCHMID

Thornton, H. G., and H. NICOL

Trumble, H. C., and R. E. Shapter

Trumble, H. C., and T. H. STRONG

TUKEY Jr., H. B., H. B. Tukey Sr. and S. H. WITTWER

Tukey Jr., H. B., and H. B. Tukey Sr.

VIRTANEN, A. I., and S. V. HAusen

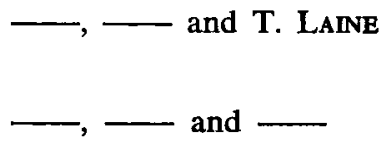

WAgner, R. E. and H. L. WILKINS

WALKER, T. W., A. F. R. Adams and H. D. ORCHISTON WALKER, T. W., H. D. Orchiston and A. F. R. ADAMS

WATKIns, J. M.

WILSON, J. K.

and J. C. Burton
WILsON, P. W., and
O. WYSS
WIT, C. T. DE
WYSS, O., and
P. W. WILsON
YOUNG, DOROTHY J. B.

1960 The production and botanical composition of alfalfa-grass combinations and the influence of the legume on the associated grasses. Agron. J. 52, 267-269.

1934 Further evidence upon the nitrogen uptake of grass grown with lucerne. J. agric. Sci. 24, 540-543.

1937 The influence of nitrogen and phosphorus treatment on the yield and chemical composition of Weimmera ryegrass and subterranean clover, grown separately and in association. Connc. Sci. and Ind. Res. (Austr.) Bull. No. 105, 25-36.

1937 On the nitrogen accretion of pasture grasses when grown in association with legumes. Connc. Sci. and Ind. Res. (Austr.) Bull. No. $105,11-24$.

1958 Loss of nutrients by foliar leaching as determined by radioisotopes. Proc. Am. Soc. hort. Sci. 71, 496-506.

1962 The loss of organic and inorganic materials by leaching from leaves and other aboveground plant parts. Proc. Radioisotopes in soil-plant nutrition studies Vienna. 289-302.

1936 Investigations on the root nodule bacteria of leguminous plants. XVII. Continued investigations on the effect of air content of the medium on the development and function of the nodule. $J$. agric. Sci. 26, 281-287.

1937a — XIX. Influence of various factors on the excretion of nitrogenous compounds from the nodules. J. agric. Sci. 27, $332-348$.

$1937 \mathrm{~b}-\mathrm{XX}$. Excretion of nitrogen in associated cultures of legumes and non-legumes. J. agric. Sci. 27, 584-610.

1954 Legume nitrogen versus fertilizer nitrogen in protein production of forage. Agron. J. 46, 233-237.

1947 The effect of legumes on the percentage of crude protein in orchard grass and brome grass at Beltsville, Md, during 1945. J. Am. Soc. Agron. 39, 141-145.

1956 Fate of labeled nitrate and ammonium nitrogen when applied to grass and clover, grown separately and together. Soil Sci. 81, 329-351.

1954 The nitrogen economy of grass legume associations. $J$. Br. Grassl. Soc. 9, 249-274.

1940 The growth habits and chemical composition of Brome grass, Bromus inermis LEYSS, as affected by different environmental conditions. J. Am. Soc. Agron. 32, 527-538.

1942 The loss of nodules from legume roots and its significance. J. Am. Soc. Agron. 34, 460-471.

1938 Excretion of nitrogen by leguminous plants. J. agric. Sci. 28, $307-323$.

1937 Mixed cropping and the excretion of nitrogen by leguminous plants. Proc. Soil Sci. Soc. Am. 2, 289-297.

1960 On competition. Versl. Landbk. Onderz. 66.8, 80 pp.

1958 Over concurrentie. Jaarb. I.B.S. 59-73.

1941 Factors influencing excretion of nitrogen by legumes. Soil Sci. 52, 15-30.

1958 A study of the influence of nitrogen on the root weight and nodulation of white clover in a mixed sward. J. Br. Grassl. Soc. 13, 106-114. 